\title{
Preparation of Optically Active Tertiary Alcohols by Enzymatic Methods. Application to the Synthesis of Drugs and Natural Products
}

\author{
Same-Ting Chen and J im-Min Fang* \\ Department of Chemistry, National Taiwan University, Taipe 106, Taiwan, Republic of China
}

Received February 10, $1997^{\otimes}$

\begin{abstract}
By the catalysis of AK or porcine pancreas lipases, 3-iodo-2-phenyl-1,2-propanediol, 1-(hydroxymethyl)-1-phenyloxirane, 2-(iodomethyl)-4-phenyl-3-butyne-1,2-diol, 2-(iodomethyl)-4-(trimethylsilyl)-3-butyne-1,2-diol, and 5,5-dimethyl-2-(iodomethyl)-3-hexyne-1,2-diol were resolved in very high enantioselectivities $(E \geq 153)$. The obtained enantiomerically pure or optically enriched compounds, containing an iodo atom, an oxirane moiety, or an alkynyl group, are versatile building blocks for the synthesis of chiral azido diols, sulfanyl diols, cyano diols, the side chain of a vitamin $D_{3}$ metabolite, the $\omega$-chain of a prostaglandin analog, and an aggregation pheromone (1S,5R)-(-)frontalin. Models based on the consideration of the importance of size, distance, and electron effect are proposed to interpret the observed stereospecificity in the enzymatic reactions. Thus, thelipasecatalyzed reactions of 1,1-disubstituted 1,2-diols occurred efficiently at the primary hydroxyl groups while the enantioselectivity was controlled by the tertiary carbinyl centers.
\end{abstract}

\section{Introduction}

Tertiary alcohols and their derivatives containing tertiary $\mathrm{C}-\mathrm{O}$ bonds are useful building blocks for many drugs and natural products (Figure 1 ), such as prostaglandin analog (1), ${ }^{1}$ frontalin (2), ${ }^{2}$ and vitamin $D_{3}$ metabolite (3). ${ }^{3}$ In comparison with the great progress in preparing optically active secondary alcohols, synthesis of enantiomerically pure tertiary alcohols is still a challenging problem. The classical method for preparation of optically active tertiary alcohols is via separation of their properly derivatized diastereomers. ${ }^{4}$ For example, ${ }^{4 a}( \pm)$-3-methyl-1-pentyn-3-ol is derivatized with phthalic anhydride, and the resulting acid reacts with a natural alkaloid (-)-brucine to form salts for separation. After several recrystallizations, the separated diastereomers are saponified to give the optically active alcohols in low yields. Another common method to prepare optically active tertiary alcohols involves multistep transformations from chiral pool $s^{5}$ of natural products such as terpenes, amino acids, hydroxy acids, and carbohydrates. The asymmetric synthesis by addition of chiral organometallic reagents to unsymmetric ketones ${ }^{6}$ is a promising approach to obtain optically active tertiary alcohols. The catalytic asymmetric synthesis by dihy-

${ }^{\otimes}$ Abstract published in Advance ACS Abstracts, J une 1, 1997

(1) Bindra, J. S. In TheTotal Synthesis of Natural Products; Wiley: New York, 1981; Vol. 4, pp 353-449.

(2) Mori, K. Tetrahedron 1975, 31, 1381

(3) Partridge, J. J .; Shiuey, S.-J .; Chadha, N. K.; Baggiolini, E. G.; Blount, J . F.; Uskokovic, M. R. J. Am. Chem. Soc. 1981, 103, 1253.

(4) (a) Hickman, J. R.; Kenyon, J. J . Chem. Soc. 1955, 2051. (b) Newman, P. Optical Resolution Procedures for Chemical Compounds; Manhattan College: New York, 1984; Vol. 3, pp 1-473.

(5) (a) Hanessian, S. Total Synthesis of Natural Products: The 'Chiron' Approach; Pergamon Press: Oxford, 1983. (b) Scott, J . W. In Asymmetric Synthesis; Morrison, J . D., Scott, J. W., Eds.; Academic Press: Orlando, FL, 1984; Vol. 4, pp 1-226. (c) Ho, T. L. EnantioselectiveSynthesis: Natural Products from Chiral Terpenes; Wiley: New York, 1992.

(6) (a) Solladié, G. In Asymmetric Synthesis; Morrison, J. D., Ed.; Academic Press: Orlando, FL, 1983; Vol. 3, pp 157-199. (b) Huryn, D. M. In Comprehensive Organic Synthesis; Trost, B. M., Fleming, I., Eds.; Pergamon Press: Oxford, 1991; Vol. 1, pp 49-75. (c) Weber, B.; Seebach, D. Angew. Chem., Int. Ed. Engl. 1992, 31, 84. (d) Noyori, R. Asymmetric Catalysis in Organic Synthesis; Wiley: New Y ork, 1994; pp 255-297.

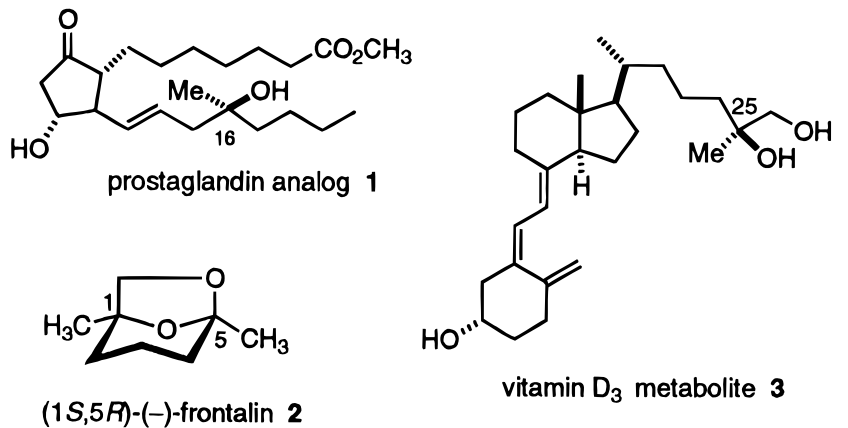

Figure 1. Exemplified natural products and drugs containing tertiary $\mathrm{C}-\mathrm{O}$ bonds.

droxylation of 1,1-disubstituted ol efins ${ }^{7}$ is so far the most effective method to prepare optically active tertiary alcohols. The catalytic asymmetric epoxidation of 1,1disubstituted ol efins, ${ }^{8}$ followed by treatment with a base or nucleophile, leads to various tertiary al cohols.

Microbial or enzymatic methods have been successfully utilized to prepare some optically active tertiary al cohols, if the substrates are not steric demanding. For example, monooxygenases ${ }^{9}$ and chloroperoxidases 9,10 are used to prepare the epoxides of some 2-methylalkenes, but these enzymes fail to catalyze the oxidation of homologous or analogous compounds having the methyl group replaced with other alkyl or phenyl groups. Epoxide hydrolases ${ }^{11}$

(7) Kolb, H. C.; VanNieuwenhze, M. S.; Sharpless, K. B. Chem. Rev. 1994, 94, 2483.

(8) (a) J ecobsen, E. N. In Catalytic Asymmetric Synthesis; Ojima, I., Ed.; VCH: New York, 1993; pp 159-202. (b) Mukaiyama, T.; Yamada, T.; Nagata, T.; Imagawa, K. Chem. Lett. 1993, 327.

(9) (a) Takahashi, O.; Umezawa, J .; Furuhashi, K.; Takagi, M. Tetrahedron Lett. 1989, 30, 1583. (b) Fang, J.-M.; Lin, C.-H.; Bradshaw, C. W.; Wong, C.-H. J . Chem. Soc., Perkin Trans. 1 1995, 967.

(10) Zaks, A.; Dodds, D. R. J . Am. Chem. Soc. 1995, 117, 10419.

(11) (a) Chen, X.-J ; Archelas, A.; Furstoss, R. J Org. Chem. 1993 58, 5528. (b) Wandel, U.; Mischitz, M.; Kroutil, W.; Faber, K.J . Chem Soc., Perkin Trans. 1 1995, 735.

(12) (a) Klibanov, A. M. Acc. Chem. Res. 1990, 23, 114. (b) Xie, Z. F. Tetrahedron: Asymmetry 1991, 2, 733. (c) Faber, K.; Riva, S. Synthesis 1992, 895. (d) Wong, C.-H.; Whitesides, G. M. Enzymes in Synthetic Organic Chemistry; Pergamon Press: Oxford, 1994; pp 70108. (e) Theil, F. Chem. Rev. 1995, 95, 2203. (f) Chen, C.-S.; Fujimoto, Y.; Girdaukas, G.; Sih, C. J . J . Am. Chem. Soc. 1982, 104, 7294. 
have been used in selective hydrolysis of epoxides, such as the epoxides of fumaric acid and 1-methyl-1-alkyloxiranes. Lipases ${ }^{12}$ are generally used to resolve secondary alcohols. Appropriate derivatives of some less hindered tertiary alcohols, such as the cyanohydrin acetates of n-alkyl methyl ketones, ${ }^{13}$ the acetates of 1-alkyl-1phenyl propargyl al cohols, ${ }^{14}$ the chloroacetates of bicyclo[4.1.0] heptanols, ${ }^{15}$ and an isopropyl oxalate of 2-methylbicyclo[2.2.1] heptan-2-ol, ${ }^{16}$ have been hydrolyzed by the catalysis of lipases. However, tertiary al cohols of other types are usually too bulky to have access to the active sites of lipases.

As shown in the lipase-catalyzed hydrolysis of the oxalate, ${ }^{16}$ the enzymatic reaction obviously occurs at the moiety of the isopropyl ester, while a modest enantioselectivity $(E \leq 7)$ is obtained via the stereochemical bias of the tertiary carbinyl center. This is so far the single example that clearly demonstrates a possible way, by extension of the reactive site distal from the tertiary carbinyl center, to circumvent the steric problem in the lipase-catalyzed reactions. We attempted to establish a general enzymatic method for resolution of tertiary alcohols by the similar approach, i.e, to find the derivatives suitable for enantiosel ective hydrolyses even though the reactive sites are distal from the chiral carbinyl centers.

\section{Results and Discussion}

Since a carbonate is more apt to hydrolysis than the corresponding ester, ${ }^{17}$ we examined whether the carbonate of a tertiary alcohol, ( \pm )-2-benzyl-2-hexanol (4), could be hydrolyzed by the catalysis of lipases. Hydrolysis of the ethyl carbonate 5 (Scheme 1) by the catalysis of lipase OF in aqueous DMF solution $(5 \%, \mathrm{pH} 7.8)$ proceeded sluggishly. After the mixture was stirred at room temperature for 12 days, only $1.5 \%$ of the carbonate was hydrolyzed to give the optically enriched al cohol (33\% ee favoring the more retained enantiomer on a Chiralcel OD column). The enzymatic hydrolysis of the corresponding butyl carbonate or benzyl carbonate under similar conditions was also not efficient.

We prepared a hydroperoxide $( \pm)-6$ from the parent tertiary alcohol, $( \pm)$-2-phenyl-2-hexanol $\left(30 \% \mathrm{H}_{2} \mathrm{O}_{2}\right.$, cataIytic $\mathrm{H}_{2} \mathrm{SO}_{4} ; 89 \%$ yield). This hydroperoxide exhibited a reactive site (toward lipases) more remote from the carbinyl center. If the hydroperoxide $\mathbf{6}$ were resolved via the lipase-catalyzed reaction, the obtained optically active products could be reduced to give the parent tertiary al cohols. However, attempts of acetylation of $( \pm)-6$ with vinyl acetate (or isopropenyl acetate) in an organic solvent (i- $\mathrm{Pr}_{2} \mathrm{O}$ or EtOAc) by the catalysis of lipases (AY, MY, OF , AP-6, MAP, or PPL) failed. The hydroperoxide was then acetylated by a chemical method $\left(\mathrm{Ac}_{2} \mathrm{O}, \mathrm{DMAP}\right.$, $\mathrm{THF}, 0-30{ }^{\circ} \mathrm{C}, 30 \mathrm{~min}$ ) to give the hydroperoxy acetate $( \pm)-7$ in $98 \%$ yield. The acetate 7 decomposed in water; however, the enzymatic conversion of 7 to the hydroperoxide $\mathbf{6}$ was carried out by a PPL-catalyzed transesterification with $\mathrm{n}-\mathrm{BuOH}$. Due to the instability of $\mathbf{7}$ in protic solvents, the lipase-catalyzed reaction afforded, after 5

(13) Ohta, H.; Kimura, Y.; Sugano, Y.; Sugai, T. Tetrahedron 1989, 45, 5469. 947.

(14) O'Hagan, D.; Zaidi, N. A. J . Chem. Soc., Perkin Trans. 11992

(15) Barnier, J .-P.; Blanco, L.; Rousseau, G.; Guibe-J ampel, E.; Fresse, I. J . Org. Chem. 1993, 58, 1570.

(16) Brackenridge, I.; McCague, R.; Roberts, S. M.; Tuner, N. J . J . Chem. Soc., Perkin Trans. 1 1993, 1093.

(17) Shieh, W.-R.; Gou, D.-M.; Chen, C.-S. J . Chem. Soc., Chem. Commun. 1991, 651 .
Scheme 1. Lipase-Catalyzed Reactions of the Carbonate 5, Hydroperoxy Acetate 7, and $\beta$-Alkoxy Alcohol $8^{a}$

1.

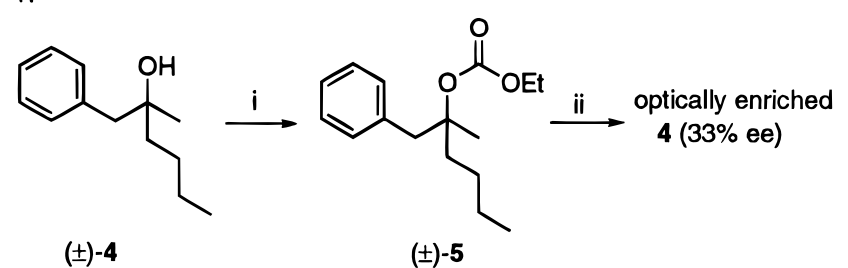

2.

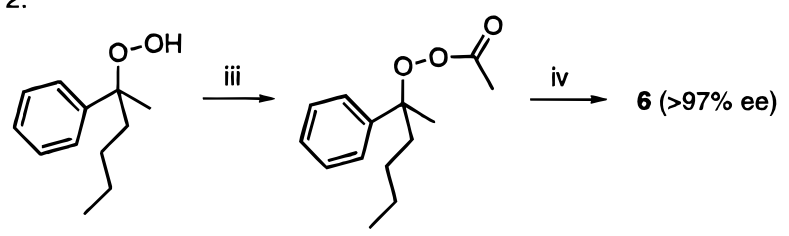

$( \pm)-6$

$( \pm)-7$

3.

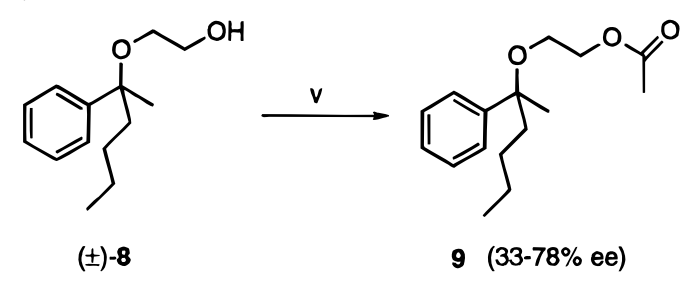

a Reagents and conditions: (i) $\mathrm{BuLi}, 0{ }^{\circ} \mathrm{C} ; \mathrm{ClCO}_{2} \mathrm{Et}, 0-25^{\circ} \mathrm{C}, 1$ h; $83 \%$; (ii) lipase $\mathrm{OF}, 5 \% \mathrm{DMF} / \mathrm{H}_{2} \mathrm{O}, \mathrm{pH}=7.8,30{ }^{\circ} \mathrm{C}, 12$ days; $1.5 \%$ conversion; (iii) $\mathrm{Ac}_{2} \mathrm{O}$, DMAP, THf, $0-30{ }^{\circ} \mathrm{C}, 30 \mathrm{~min} ; 98 \%$; (iv) $\mathrm{PPL}, \mathrm{BuOH}, 30^{\circ} \mathrm{C}, 5$ days; $6 \%$ yeild; (v) lipase, isopropenyl acetate, t-BuOMe, $30^{\circ} \mathrm{C}, 4-48 \mathrm{~h} ; 9.5-37 \%$ conversion.

days, only $6 \%$ of the enantiomerically pure hydroperoxide 6 according to the HPLC analysis on a Chiralcel OD column. The $\beta$-alkoxy alcohol $( \pm)$-8, a model compound of derivatized tertiary alcohol with a further extended reactive site, was prepared by treatment of the ethylenediol acetal of acetophenone with BuL $\mathrm{i}$ in the presence of $\mathrm{BF}_{3} \cdot \mathrm{OEt}_{2}$. Acetylations of $( \pm)-\mathbf{8}$ by the catalysis of $\mathrm{MY}$, AK, PPL, or MAP lipases occurred with reasonable rates to give the acetate 9 in $33-78 \%$ ee. The enantioselectivity $(E=2.4-9.4)$ was comparable to that found in the lipase-catalyzed hydrolysis of oxalate; ${ }^{16}$ even the reactive site of $\mathbf{8}$ was more distal from the carbinyl center.

We inferred from the above studies that tertiary alcohols containing an adjacent hydroxyl group, such as 1,1-disubstituted 1,2-diols, would be the substrates of choice for the lipase-catalyzed reactions in the sense of both efficacy and enantioselectivity. By analogy to the conventional model $\mathrm{s}^{18}$ for the lipase-catalyzed reactions

(18) (a) Ehrler, J .; Seebach, D. Liebigs Ann. Chem. 1990, 379. (b) J ohnson, C. R.; Golebiowski, A.; McGill, T. K.; Steensma, D. H. Tetrahedron Lett. 1991, 32, 2597. (c) Kazlauskas, R. J .; Weissfloch, A N. E.; Rappaport, A. T.; Cuccia, L. A. J . Org. Chem. 1991, 56, 2656. (d) Burgess, K.; J ennings, L. D. J . Am. Chem. Soc. 1991, 113, 6129. (e) Hultin, P. G.; J ones, J. B. Tetrahedron Lett. 1992, 33, 1399. (f) Guanti, G.; Banfi, L.; Narisano, E. J . Org. Chem. 1992, 57, 1540. (g) Wimmer, Z. Tetrahedron 1992, 48, 8431. (h) Ader, U.; Andersch, P.; Berger, M.; Goergens, U.; Seemayer, R.; Schmeider, M. Pure Appl. Chem. 1992, 64, 1165. (i) Kim, M.-J .; Choi, Y., K.J . Org. Chem. 1992, 57, 1605. (j) Cygler, M.; Grochulski, P.; Kazlauskas, R. J .; Schrag, J . D.; Bouthillier, F.; Rubin, B.; Serreqi, A. N.; Gupta, A. K.J. Am. Chem. Soc. 1994, 116, 3180. (k) Weissfloch, A. N. E.; Kazlauskas, R. J. J. Org. Chem. 1995, 60, 6959. 

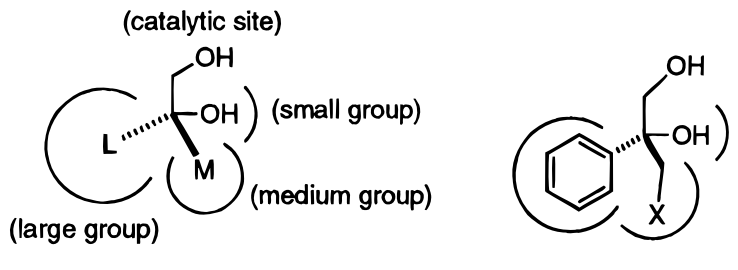

A

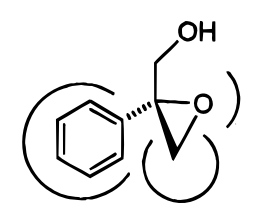

C

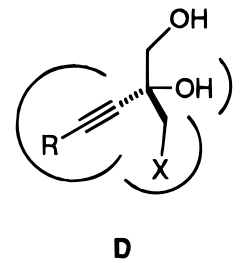

D

Figure 2. Models for the lipase-catalyzed reactions of 1,1disubstituted 1,2-diols. (A) A putative model: $L$ represents the large substituent, $M$ represents the medium substituent, and the tertiary hydroxyl group is considered as the small substituent. The primary alcohol is the reactive site, while the enantioselectivity is procured by the bias of the tertiary carbinyl center. (B) The favorable enantiomers of 2-phenyl1,2-propanediols ( $\mathrm{X}=\mathrm{H}, \mathrm{Cl}, \mathrm{Br}$, or I) for the AK lipasecatalyzed reactions. (C) The favorable enantiomer of 2-phenylglycidol for the AK lipase-catalyzed reactions. (D) The favorable enantiomers of 2-alkynyl-3-halo-1,2-propanediols (X $=\mathrm{H}, \mathrm{Cl}, \mathrm{Br}$, or I) for the porcine pancreas lipase-catalyzed reactions.

of secondary and primary alcohols, we conceived that a reaction model $\mathbf{A}$ (Figure 2 ) would be appropriate for the reactions of 1,1-disubstituted 1,2-diols, in which the tertiary hydroxyl group was assumed as the small group. High enantioselectivity could be predicted if there is sufficient discrimination of sizes between the $L, M$, and $\mathrm{OH}$ substituents. Since the enzymatic reaction would occur at the primary hydroxyl group, high efficiency is assured.

In order to test this hypothesis, we prepared $( \pm)-2-$ phenyl-1,2-propanediols $\mathbf{1 0}-\mathbf{1 3}$ and $( \pm)$-2-phenylglycidol 14 (Figure 3) and investigated their lipase-catalyzed acetylations (Table 1). The preliminary survey indicated that most lipases could be used as the catalysts for acetylations of 10-14, and the lipase AK appeared to operate with high enantioselectivity. Most of the enzymatic reactions were monitored by GC or HPLC analyses and quenched at nearly $50 \%$ conversions. The lipasecatalyzed acetylation of 10, $( \pm)$-2-phenyl-1,2-propanediol (Table 1, entries 1-3), using isopropenyl acetate as the solvent and acylating agent showed modest enantioselectivities $(E \leq 4.7)$. A previous study 19 indicated that no enantioselectivity is found in the lipase-catalyzed acetylations of $( \pm)$-2-phenyl-1,2-butanediol or ( \pm )-2-phenyl-1,2-pentanediol by using diisopropyl ether as the solvent. For 1-substituted 1,2-diols, ${ }^{20}$ the lipase-catalyzed acetylations occur first at the primary hydroxyl groups with little enantioselectivity, but the subsequent acetylations at the secondary hydroxyl groups exert high enantioselectivity. In the present study of the 1,1disubstituted 1,2-diols, the lipase-catalyzed acetylations occurred at the primary hydroxyl groups and enantioselectivity was procured simultaneously by the stereochemical bias of the tertiary carbinyl centers. We also found

(19) H of, R. P.; Kellog, R. M. Tetrahedron: Asymmetry 1994, 5, 565. (20) (a) J anssen, A. J. M.; Klunder, A. J . H.; Zwanenburg, B. Tetrahedron 1991, 47, 7409. (b) Basetti, A.; Bianchi, D.; Cesti, P.; Golini, P.; Spezia, S. J . Chem. Soc., Perkin Trans. 1 1992, 2395.<smiles>[X]CC(O)(CO)c1ccccc1</smiles><smiles>[X]C(O)(OC(C)=O)c1ccccc1</smiles>

racemic mixture

(R)-isomer<smiles>OCC1(c2ccccc2)CO1</smiles>

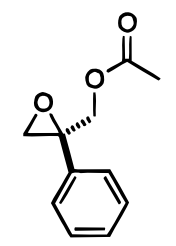

$( \pm)-14$

(S)-14a<smiles>[X]C(O)(CO)CC#C</smiles>

racemic mixture 10a

$11 a$

$12 \mathbf{a}$
$13 \mathbf{a}$
$X=B$<smiles>[R]C#C[C@@](O)(C[X])COC(C)=O</smiles>

(R)-isomer

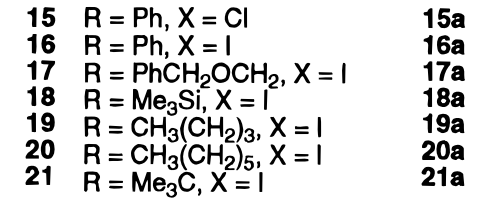<smiles>OCC(O)(CI)CCc1ccccc1</smiles>

$( \pm)-22$

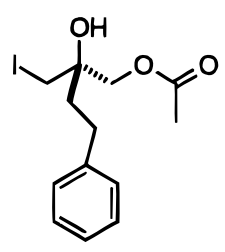

$(R)$-22a

Figure 3. Alcohol substrates and the major products in the lipase-catalyzed acetylations (Tables 1 and 2).

that high enantioselectivity in lipase-catalyzed acetylations could be achieved by introduction of halo substituents, compared the substrates $\mathbf{1 1}-\mathbf{1 3}(\mathrm{X}=\mathrm{Cl}, \mathrm{Br}$, and I) with $\mathbf{1 0}(X=H)$. As shown in Table 1, these reactions were best conducted with lipase AK using isopropenyl acetate or vinyl acetate as the solvent and acylating agent. Enantioselectivity increased as the size of the halo substituent increased, $E=11.5$ for the chl oro compound 11 (Table 1, entry 4), $E=13$ for the bromo compound 12 (Table 1, entry 9), and $\mathrm{E}=69$ for the iodo compound $\mathbf{1 3}$ (Table 1, entry 10). In this series of lipase AK-catalyzed acetylations, the best result ( $\mathrm{E}=153$ at $51 \%$ conversion) was obtained with the substrate $( \pm)$-2-phenylglycidol (14). The reaction using isopropenyl acetate as the solvent and acylating agent proceeded smoothly at room temperature to give the acetate 14a in $94 \%$ ee, accompanied by a recovery of the alcohol $\mathbf{1 4}$ in $>97 \%$ ee (Table 1, entry 12). The immobilized li pase AK was also utilized to catalyze acetylations in good enantiosel ectivities ( $E=23-101$, Table 1, entries 13-17).

The ee values and absolute configurations of the acetate products and the remaining alcohols were deter- 
Table 1. Lipase-Catalyzed Acetylations of Alcohols 10-14, Giving Acetates 10a-14a

\begin{tabular}{|c|c|c|c|c|c|c|c|c|c|}
\hline entry & substrate & lipase & solvent & $\begin{array}{l}\text { reaction } \\
\text { temp } /{ }^{\circ} \mathrm{C}\end{array}$ & $\begin{array}{l}\text { reaction } \\
\text { time/h }\end{array}$ & convn/\% & $\begin{array}{c}\mathrm{ee}_{\mathrm{s}}, \% / \\
\text { configna }^{\mathrm{a}}\end{array}$ & $\begin{array}{c}\text { eep, \%/ } \\
\text { configna }\end{array}$ & $\mathrm{E}^{\mathrm{a}}$ \\
\hline 1 & 10 & MAP & $I P A^{b}$ & 40 & $>48$ & 25 & $5 / S$ & $15 / \mathrm{R}$ & 1.4 \\
\hline 2 & 10 & AK & $\mathrm{IPA}^{\mathrm{b}}$ & 21 & 29 & 35 & $15 / S$ & $27 / R$ & 2.0 \\
\hline 3 & 10 & AP-6 & $I^{P} A^{b}$ & 40 & $>48$ & 25 & $20 / 5$ & $60 / \mathrm{R}$ & 4.7 \\
\hline 4 & 11 & AK & $I^{P} A^{b}$ & 25 & 156 & 66 & $97 / S$ & $50 / R$ & 11.5 \\
\hline 5 & 11 & $M Y^{b}$ & t-BuOMe & 25 & 156 & 32 & $30 / R$ & $64 / S$ & 6.0 \\
\hline 6 & 11 & $A Y^{b}$ & t-BuOMe & 25 & 156 & 45 & 23/R & $28 / S$ & 2.0 \\
\hline 7 & 11 & $\mathrm{OF}^{\mathrm{b}}$ & t-BuOMe & 25 & 156 & 48 & $60 / R$ & $66 / 5$ & 8.5 \\
\hline 8 & 11 & $A P-6^{b}$ & t-BuOMe & 25 & 156 & 45 & $56 / S$ & $69 / R$ & 9.3 \\
\hline 9 & 12 & AK & $V A^{c}$ & 25 & 10 & 55 & $82 / 5$ & $66 / R$ & 13 \\
\hline 10 & 13 & AK & $I^{P} A^{b}$ & 25 & 30 & 43 & $70 / 5$ & $94 / \mathrm{R}$ & 69 \\
\hline 11 & 13 & $P P L b, c$ & t-BuOMe & 20 & 7.5 & 41 & $50 / S$ & $70 / R$ & 10 \\
\hline 12 & 14 & AK & $I P A^{b}$ & 21 & 4.6 & 51 & $>\mathbf{9 7} \mathrm{d} / \mathbf{S}$ & 94/S & 153 \\
\hline 13 & 14 & $\mathrm{AK}^{\mathrm{e}}$ & $I^{P} A^{b}$ & 25 & 2 & 31 & $43 / S$ & $97 / S$ & 101 \\
\hline 14 & 14 & $A K^{b, e}$ & t-BuOMe & 25 & 2 & 56 & $96 / S$ & $74 / S$ & 23 \\
\hline 15 & 14 & $A K^{b, e}$ & THF & 25 & 15 & 48 & $87 / 5$ & 93/S & 76 \\
\hline 16 & 14 & $A K^{b, e}$ & $\mathrm{PhCH}_{3}$ & 25 & 3 & 35 & $52 / S$ & $96 / S$ & 82 \\
\hline 17 & 14 & $A K^{e}$ & $V^{c}{ }^{c}$ & 25 & 2 & 59 & $>97^{d} / S$ & $68 / S$ & 39 \\
\hline
\end{tabular}

a The configuration of the major enantiomer. Enantiomeric excess of the remaining substrate, ee ${ }_{s}$, and the product, ee $e_{p}$, were determined by HPLC analysis. See ref $12 f$ and the general part of the Experimental Section for the definition of enantiomeric ratio (E value). b I sopropenyl acetate (IPA) was used as the acylating agent. ' Vinyl acetate (VA) was used as the acylating agent. ${ }^{d}$ NO enantiomer was found according to the HPLC and NMR analyses. ${ }^{2}$ Lipase AK immobilized on Hyflo Supercel was used.

mined by HPLC analyses, optical rotation measurements, and chemical correlations (Scheme 2). The (S)-enantiomer of 2-phenyl-1,2-propanediol (10) is known to be dextrorotatory; ${ }^{21}$ thus, the remaining al cohol $\mathbf{1 0}$ in entries 1-3 (Table 1) with dextrorotation should predominate in the (S)-enantiomer. The remaining chlorohydrin 11 (97\% ee, levorotatory), recovered from the lipase AKcatalyzed acetylation (Table 1, entry 4 ), was reduced by $\mathrm{Bu}_{3} \mathrm{SnH}$ to give (S)-(+)-10 (route 1).22 Thus, (-)-3-chloro2-phenyl-1,2-propanediol (11) should have the (S)-configuration. Treatment of the chlorohydrin (S)-11 with $\mathrm{K}_{2} \mathrm{CO}_{3}$ in $\mathrm{MeOH}$ yielded (S)-2-phenylglycidol (14), exhibiting levorotation. It should not be overlooked that formation of the oxirane $\mathbf{1 4}$ might also involve a Payne rearrangement (route 2). ${ }^{23}$ Fortunately, this process was stereogenically degenerative to give the identical glycidol (S)-(-)-14. Since two enantiomers of $\mathbf{1 4}$ (recovered from Table 1, entry 13) were separable on a Chiralcel OD column by elution with 2-propanol/hexane (1:9), the ee value of chlorohydrin $\mathbf{1 1}$ was double checked, by correlation with the diol $\mathbf{1 0}$ via comparison of the optical rotations or by correlation with the glycidol 14 via the HPLC analysis. The acetates (R)-(+)-11a, -12a, and -13a were saponified and converted in situ to the oxirane $(R)-$ $(+)-14$ in alkaline conditions. By this means, the ee values and absolute configurations of the halohydrins 11-13 and their corresponding acetates 11a-13a were unambiguously determined.

In order to broaden the scope of this study, we also prepared racemic 2-alkynyl-3-halo-1,2-propanediols 1521 (Figure 3) and investigated their enzymatic reactions (Table 2). The alkynyl substituents were considered to have viable synthetic application. The preliminary study of the lipase AK-catalyzed acetylations of 2-(hal omethyl)4-phenyl-3-butyne-1,2-diols $\mathbf{1 5}$ and $\mathbf{1 6}$ showed low enantioselectivity, $\mathrm{E}=1.4$ and 3.0, respectively. After several tests, we found that PPL was the proper enzyme for these substrates to be acetylated in a high enantioselective manner. The PPL-catalyzed acetylations of $\mathbf{1 5}$ and $\mathbf{1 6}$

(21) (a) Eliel, E. L.; Freeman, J . P. J . Am. Chem. Soc. 1952, 74, 923. (b) Crispino, G. A.; J eong, K.-S.; Kolb, H. C.; Wang, Z.-M.; Xu, D.; Sharpless, K. B. J . Org. Chem. 1993, 58, 3785.

(22) Wang, Z.-M.; Sharpless, K. B. Synlett 1993, 603.

(23) (a) Payne, G. B. J . Org. Chem. 1962, 27, 3819. (b) Behrens, C. H.; Ko, S. Y.; Sharpless, K. B.; Walker, F. J . J . Org. Chem. 1985, 50, 5687. (c) Hanson, R. M. Chem. Rev. 1991, 91, 437. using vinyl acetate as the solvent and acylating agent (Table 2, entries 4 and 6) resulted in high enantioselectivity with the E values 72 and 18 . The enantioselectivity was improved dramatically by conducting the acetylation in an aprotic solvent; for instance, acetylation of $\mathbf{1 6}(\mathrm{R}=$ $\mathrm{Ph}$ ) was achieved with $\mathrm{E}=211$ in toluene and $\mathrm{E}>1000$ in tert-butyl methyl ether (Table 2, entries 7 and 8). The PPL-catalyzed acetylations of the al kynyl compounds $\mathbf{1 8}$ $\left(\mathrm{R}=\mathrm{Me}_{3} \mathrm{Si}\right)$ and $\mathbf{2 1}\left(\mathrm{R}=\mathrm{Me}_{3} \mathrm{C}\right)$ containing bulky $\mathrm{R}$ groups also demonstrated excellent enantioselectivities $(\mathrm{E}=368$ and 751) under similar conditions (Table 2, entries 10 and 13). Ther efore, nearly enantiomerically pure al cohol $(\mathbf{1 6}, \mathbf{1 8}$, or $\mathbf{2 1})$ and acetate $(\mathbf{1 6 a}, 18 \mathbf{a}$, or $\mathbf{2 1 a})$ were obtained simultaneously by this enzymatic method. The alkynyl compounds $\mathbf{1 7}(\mathrm{R}=$ (benzyloxy)methyl), 19 $(\mathrm{R}=\mathrm{n}$-butyl), and $\mathbf{2 0}(\mathrm{R}=\mathrm{n}$-hexyl) containing $\mathrm{R}$ groups of medium sizes underwent PPL-catalyzed acetylations in modest to high enantioselectivities, $E=24,47$, and 10 , respectively. The $E$ values of the PPL-catalyzed acetylations decreased when the alkynyl group was replaced with other substituents, such as in the reactions of $\mathbf{1 3}$ (having a phenyl substituent, entry 11 of Table 1 , $\mathrm{E}=10$ ) and 22 (having a $\beta$-phenylethyl substituent, entry 14 of Table 2, $\mathrm{E}=6.5$ ).

Enantiomers of the alcohols $\mathbf{1 5 - 1 7}$ and the acetates 15a-17a were resolvable on a Chiralcel OD col umn, so that the ee values of these compounds in the related enzymatic reactions were readily determined by the HPLC analyses. Otherwise, the diols 18-21 and the acetates 18a-21a were treated with $\mathrm{K}_{2} \mathrm{CO}_{3}$ to give 2-alkynylglycidols 24-27 (route 2, Scheme 2), of which ee values were determined by HPLC analyses. In the case of 21, its enantiomers were also resolvable on a Chiralcel OD column. The measured ee value by this means was in agreement with that deduced from the chemical correlation with glycidol 27. The experiments also confirmed that no racemization occurred on treating $\mathbf{2 1}$ in alkaline conditions to give $\mathbf{2 7}$. The remaining alcohol (-)-16 recovered from the PPL-catalyzed acetylation (Table 2, entry 8) was determined to have the (S)configuration by correlation with a known compound, 2-methylglycerol acetonide ${ }^{24} \mathbf{3 0}$ (route 3 ). Thus, theiodo compound (S)-(-)-16 was reduced with $\mathrm{Bu}_{3} \mathrm{SnH}$ or $\mathrm{LiAlH}_{4}$

(24) Dung, J .-S.; Armstrong, R. W.; Anderson, O. P.; Williams, R. M. J. Org. Chem. 1983, 48, 3592. 


\section{Scheme 2. Determination of Enantiomeric Excesses and Absolute Configurations of 1,1-Disubstituted 1,2-Diolsa}

1.<smiles>[X]C[C@@](O)(CO)c1ccccc1</smiles>

(S)-(-)-11, X = Cl (S) $-(-)-12, X=\mathrm{Br}$ $(S)-(-)-13, X=1$

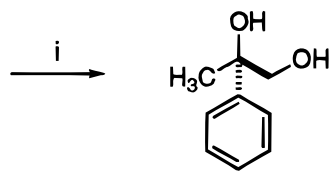

$(S)-(+)-10$

compound of known absolute configuration

2.

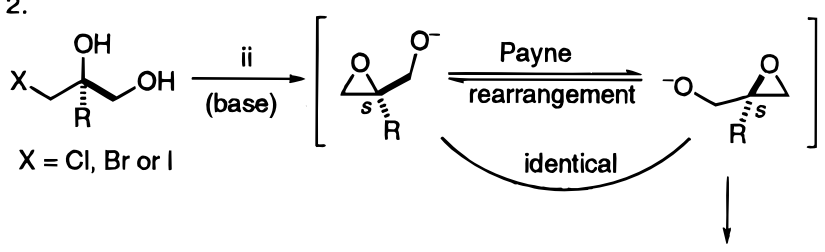

$(S)-11,(S)-12,(S)-13 \quad \mathrm{R}=\mathrm{Ph}$

(S) $-16 \quad \mathrm{R}=\mathrm{PhCC}$

(S)-18 $\quad \mathrm{R}=\mathrm{Me}_{3} \mathrm{SiCC}$

(S) $-19 \quad \mathrm{R}=\mathrm{Me}\left(\mathrm{CH}_{2}\right)_{3} \mathrm{CC}$

(S)-20 $\mathrm{R}=\mathrm{Me}\left(\mathrm{CH}_{2}\right)_{5} \mathrm{CC}$

(S)-21
(S)-14

(S)-23

(S)-24

(S)-25

(S)-26

(S)-27

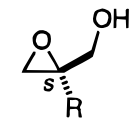

determination of ee values by HPLC

3.

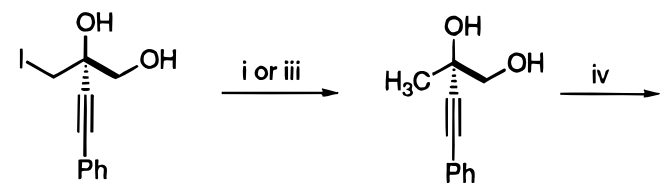

$(S)-(-)-16$

$(S)-28$

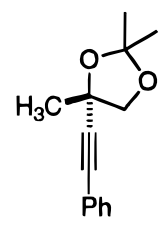

$(S)-29$

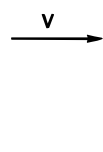$$
\text { compound of known }
$$

a Reagents and conditions: (i) $\mathrm{Bu}_{3} \mathrm{SnH}, \mathrm{AIBN}, \mathrm{PhH}$, reflux $4 \mathrm{~h}$; $70 \%$; (ii) $\mathrm{K}_{2} \mathrm{CO}_{3}, \mathrm{MeOH}, 30^{\circ} \mathrm{C}, 8 \mathrm{~h} ; 90 \%$; (iii) $\mathrm{LiAlH}_{4}, \mathrm{Et}_{2} \mathrm{O}, 30^{\circ} \mathrm{C}$, 2 h; 74\%; (iv) p-TsOH, $\mathrm{CuSO}_{4}, \mathrm{Me}_{2} \mathrm{CO}, 25^{\circ} \mathrm{C}, 4 \mathrm{~h}$; (v) $\mathrm{O}_{3}, \mathrm{MeOH}$, $0{ }^{\circ} \mathrm{C}(1.5 \mathrm{~h})$, reflux (15 min); then $\mathrm{LiAlH}_{4}, \mathrm{THF}, 25^{\circ} \mathrm{C}, 12 \mathrm{~h} ; 17 \%$ from 28 to 30.

to give a diol (S)-28. After protection of the diol as the acetonide, the triple bond was cleaved with ozone, followed by reduction with $\mathrm{LiAlH}_{4}$, to give (S)-(-)-30, $[\alpha]^{25} \mathrm{D}$ -7.61 (lit. ${ }^{24}[\alpha]^{25} \mathrm{D}-5.33$ ).

On the basis the assumption that the PPL-catalyzed acetylations proceeded in a consistent mechanism, all the remaining alcohols 16-22 were considered to predominate in the (S)-enantiomers and the major products 16a22a should predominate in the ( $R$ )-enantiomers. These assignments were supported by the eluting orders on a Chiralcel OD column. For example, the (S)-alcohol $\mathbf{1 6}$ (major enantiomer) and (S)-acetate 16a (minor enantiomer) were more retained than their corresponding ( $R$ )enantiomers. The similar eluting order for the enantiomeric pairs of 15, 15a, 17, 17a, and 21 was observed.

The acetylations of $( \pm)$-2-phenyl-1,2-propanediols $\mathbf{1 0}$ 13, ( \pm )-2-phenylglycidol (14), and ( \pm )-2-alkynyl-1,2-propanediols 15-21 using li pases AK, PPL, MAP, and AP-6 as the catalysts exhibited a consistent enantiotopic preference for the formation of (R)-acetates $10 \mathbf{a}-13 \mathbf{a}$, (S)$\mathbf{1 4 a}$ (noting the different S-notation for $\mathbf{1 4 a}$ according to the convention of Cahn-Ingold-Prelog sequence rul ${ }^{25}$ ), and (R)-acetates 15a-21a. The model $\mathbf{A}$, which was hypothesized at the outset of this study, seems appropriate to explain the observed enantiotopic preference in the li pase-catalyzed reactions of 1,1-disubstituted 1,2-diols. For 11-13 (Figure 2, model B), the phenyl, halomethyl, and hydroxyl groups of the substrate are placed in the large, medium, and small pockets, respectively. The glycidol $\mathbf{1 4}$ fits the model $\mathbf{C}$ very well and shows the utmost enantiotopic preference. For 15-21 (model D), we assume the al kynyl group is closer to the stereogenic center due to the sp hybrid nature of the triple bond. This substituent, especially that in 16, 18, or $\mathbf{2 1}$ containing a bulky phenyl, trimethylsilyl, or tert-butyl moiety at the terminal of the triple bond, is thus the most steric demanding and placed in the large pocket of the enzyme. The $\mathrm{C}-\mathrm{I}$ bond is rather long, and the iodomethyl group is considered to be located in the medium pocket. The hydroxyl group is in the small pocket to cope with the observed high enantiosel ectivity. The previous study ${ }^{19}$ also shows that enantioselectivity of lipase-catalyzed acetylations can be determined by the subtle effect of a double bond in the substrates. For example, ${ }^{19}$ the lipasecatalyzed acetylation of ( \pm )-2-phenylhexane-1,2-diol proceeds without any enantiomeric preference, whereas the reaction of $( \pm)$-2-phenyl-4-hexene-1,2-diol shows a modest enantioselectivity $(E=16)$. By comparison of the excellent $E$ value in the PPL-catalyzed hydrolysis of 2-(iodomethyl)-4-phenyl-3-butyne-1,2-diol (16) (E > 1000) with those of 2-(iodomethyl)-4-phenyl butane-1,2-diol (22) (E $=6.5$ ) and 3-iodo-2-phenyl-1,2-propanediol (13) $(E=10)$, the enhancement of enantioselectivity in $\mathbf{1 6}$ by the effect of a triple bond is dramatic.

It is noted that acetylations of $\mathbf{1 1}$ and $\mathbf{1 5}$ using Candida cylindracea lipases MY, AY, or OF as catalysts (entries 5-7 in Table 1 and entries 2-3 in Table 2) showed the opposite enantiotopic preference. This result may reflect the different nature of the lipases of Candida genus, but the elucidation of the real mechanism awaits further investigation.

Synthetic Application. The optically active tertiary alcohols containing halo atoms or oxirane moieties are especially useful for functional group transformation and $\mathrm{C}-\mathrm{C}$ bond formation. The glycidol (S)-14 was subjected to nucleophilic substitutions with $\mathrm{NaN}_{3}, \mathrm{PhSH}$, and $\mathrm{HCN}$ (generated from the cyanohydrin of acetone) to give, respectively, the azido diol (R)-31, the sulfanyl diol (S)32, and the cyano diol (S)-33 in a stereospecific manner (Scheme 3, route 1). The methyl ether of (S)-14 reacted with $\mathrm{PhLi}$ in the presence of $\mathrm{CuCN}$ to afford the tertiary alcohol (S)-41 in 88\% yield. Treatment of the iodohydrin (R)-16 with $\mathrm{NaN}_{3}$ in DMF at $70^{\circ} \mathrm{C}$ yielded the azido diol (S)-34 in 94\% yield. The product might be obtained directly by an $\mathrm{S}_{\mathrm{N}} 2$ mechanism or via the intermediacy of the glycidol (R)-23 (route 2). Indeed, (R)-23 was found when the reaction of (R)-16 with $\mathrm{NaN}_{3}$ was performed at a lower reaction temperature $\left(25^{\circ} \mathrm{C}\right)$. The glycidol (R)$\mathbf{2 3}$ was isolated from the reaction of (R)-16 with $\mathrm{PhSNa}$ and subsequently converted to the sulfanyl diol (R)-35 on treatment with $\mathrm{PhSH}-\mathrm{Et}_{3} \mathrm{~N}$. As phenylsulfanyl group is known to be a good leaving group, (R)-23 and (R)-35 might be interconvertible, and the equilibrium was dependent of the reaction conditions. The nucleophilic

(25) Cahn, R. S.; Ingold, C.; Prelog, V. Angew. Chem., Int. Ed. Engl. 1966, 5, 385. 
Table 2. Lipase-Catalyzed Acetylations of Alcohols 15-22 with Vinyl Acetate, Giving Acetates 15a-22a

\begin{tabular}{|c|c|c|c|c|c|c|c|c|c|}
\hline entry & substrate & lipase & solvent & $\begin{array}{l}\text { reaction } \\
\text { temp } /{ }^{\circ} \mathrm{C}\end{array}$ & $\begin{array}{c}\text { reaction } \\
\text { time/h }\end{array}$ & convn/\% & $\begin{array}{c}e_{s,} \% / \\
\text { confign }^{a} \\
\end{array}$ & $\begin{array}{c}e_{p}, \% / \\
\text { confign }^{a} \\
\end{array}$ & $E$ \\
\hline 1 & 15 & AK & $\mathrm{VA}^{\mathrm{b}}$ & 25 & n.a.c & 48 & $11 / \mathrm{S}$ & $12 / \mathrm{R}$ & 1.4 \\
\hline 2 & 15 & AY & $V^{b}$ & 25 & n.a. ${ }^{c}$ & 26 & $22 / R$ & $62 / S$ & 5.2 \\
\hline 3 & 15 & OF & $V^{b}$ & 25 & n.a.c ${ }^{c}$ & 35 & $24 / R$ & $45 / S$ & 3.3 \\
\hline 4 & 15 & PPL & $\mathrm{VA}^{\mathrm{b}}$ & 25 & 4 & 41 & $67 / S$ & 95/R & 72 \\
\hline 5 & 16 & $A K$ & $V^{b}$ & 15 & 3.5 & 21 & $12 / S$ & $46 / R$ & 3.0 \\
\hline 6 & 16 & PPL & $\mathrm{VA}^{\mathrm{b}}$ & 19 & 3 & 63 & $97 / S$ & $56 / R$ & 18 \\
\hline 7 & 16 & PPL & $\mathrm{PhCH}_{3}$ & 19 & 7.7 & 51 & $>97^{d} / S$ & $96 / R$ & 211 \\
\hline 8 & 16 & PPL & t-BuOMe & 19 & 9 & 50 & $>97^{d} / \mathbf{S}$ & $>97^{d} / R$ & $>1000$ \\
\hline 9 & 17 & PPL & t-BuOMe & 19 & 21 & 64 & $>97 \mathrm{~d} / S$ & $55 / R$ & 24 \\
\hline 10 & 18 & PPL & t-BuOMe & 30 & 23 & 51 & $>97^{\mathrm{d}} / \mathrm{S}$ & 94/R & 368 \\
\hline 11 & 19 & PPL & t-BuOMe & 30 & 4 & 49 & $88 / 5$ & $89 / R$ & 47 \\
\hline 12 & 20 & PPL & t-BuOMe & 30 & 5 & 64 & $93 / \mathrm{S}$ & $51 / R$ & 10 \\
\hline 13 & 21 & PPL & t-BuOMe & 20 & 5.3 & 49 & $94 / S$ & $>\mathbf{9 7} / \mathbf{R}$ & 751 \\
\hline 14 & 22 & PPL & t-BuOMe & 18 & 3 & 51 & $59 / 5$ & $57 / R$ & 6.5 \\
\hline
\end{tabular}

a The configuration of the major enantiomer. ${ }^{b}$ Vinyl acetate was used as the solvent and acylating agent. c The degree of acetylation was monitored by GC analysis; however, the data of reaction times are not available. ${ }^{d}$ No enantiomer was found according to the HPLC and NMR analyses.

Scheme 3. Nucleophilic Substitution Reactions of Iodohydrins and Glycidolsa

1.

1.<smiles>OCC1(c2ccccc2)CO1</smiles>

(S)-14

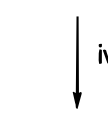<smiles>COC[C@@]1(c2ccccc2)CO1</smiles>

(R) -40<smiles>[Y]C[C@@](O)(CO)c1ccccc1</smiles><smiles>N=[Y][As]</smiles>

(S) $-32 \quad Y=P h S$ (S) $-33 \mathrm{Y}=\mathrm{CN}$<smiles>COC[C@](O)(Cc1ccccc1)c1ccccc1</smiles>

(5)-41

3.<smiles>[R]C#C[C@](O)(CO)CI</smiles>

(S) $-16 \mathrm{R}=\mathrm{Ph}$ (S) $-20 \mathrm{R}=\mathrm{CH}_{3}\left(\mathrm{CH}_{2}\right)_{5}$

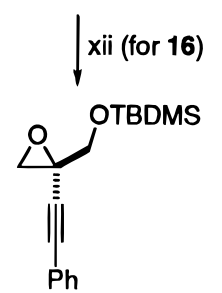

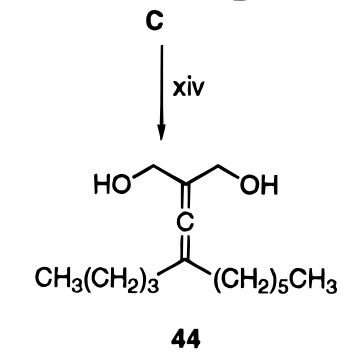

$(R)-42$<smiles>CCCCCC(O)(C#Cc1ccccc1)CO</smiles>

(S)-43

2.<smiles>CC#CC(O)(C#CCI)CI</smiles>

(R)-16 iv, $x$<smiles>COCC(O)(C#CC#N)CC(C)C</smiles>

(S)-38<smiles>OC[C@@]1(C#Cc2ccccc2)CO1</smiles>

(R)-23<smiles>[Y]C#CC(O)(CO)CO</smiles>

(S) $-34 \begin{aligned} & Y=N_{3} \\ & (R)-35 Y=P h S\end{aligned}$ (R) $-36 \mathrm{Y}=\mathrm{CN}$<smiles>COC[C@@H]1CN1</smiles>

(R)-39

partial racemization

a Reagents and conditions: (i) for 31, $\mathrm{NaN}_{3}, \mathrm{NH}_{4} \mathrm{Cl}, \mathrm{MeOH}, \mathrm{H}_{2} \mathrm{O}$, reflux, $5.5 \mathrm{~h} ; 57 \%$; (ii) for 32, $\mathrm{PhSH}, \mathrm{Et}_{3} \mathrm{~N}, 25^{\circ} \mathrm{C}, 15 \mathrm{~h}$; $71 \%$; (ii) for 33, $\mathrm{Me}_{2} \mathrm{C}(\mathrm{OH}) \mathrm{CN}$, cat. $\mathrm{KCN}, 25^{\circ} \mathrm{C}, 24 \mathrm{~h} ; 42 \%$; (iv) NaH, THF, $\mathrm{Me}_{2} \mathrm{SO}_{4}, 25^{\circ} \mathrm{C}, 1$ h; 99\%; (v) PhLi (3 equiv), CuCN (1.5 equiv), THF, Et $\mathrm{O}_{2} \mathrm{O}$, hexane, -78 to $0{ }^{\circ} \mathrm{C}, 1.5 \mathrm{~h}$; $88 \%$; (vi) PhSNa, DMSO, $60{ }^{\circ} \mathrm{C}, 5 \mathrm{~h} ; 87 \%$; (vii) for 34, treating 16 with $\mathrm{NaN}_{3}$ in $\mathrm{DMF}-\mathrm{H}_{2} \mathrm{O}, 70{ }^{\circ} \mathrm{C}, 2 \mathrm{~h}$; $94 \%$; (viii) for 35, treating 23 with $\mathrm{PhSH}, \mathrm{Et}_{3} \mathrm{~N}, 25^{\circ} \mathrm{C}, 15 \mathrm{~h}$; 75\%; (ix) for 36, treating 16 with $\mathrm{KCN}$ in DMSO, $25^{\circ} \mathrm{C}, 13 \mathrm{~h}$; $86 \%$; $(\mathrm{x}) \mathrm{NaN}$ $\mathrm{MeOH}, \mathrm{H}_{2} \mathrm{O}$, reflux $2 \mathrm{~h} ; 75 \%$; (xi) $\mathrm{Ph}_{3} \mathrm{P}, \mathrm{CH}_{3} \mathrm{CN}, 23{ }^{\circ} \mathrm{C}$, $5 \mathrm{~h}$; $71 \%$; (xii) $\mathrm{NaH}$, THF, t-BuMe $\mathrm{SiCl}_{2} 25^{\circ} \mathrm{C}, 3 \mathrm{~h} ; 88 \%$; $(x i i i) \mathrm{CH}_{3}\left(\mathrm{CH}_{2}\right)_{11} \mathrm{MgBr}$, $\mathrm{THF}, 0{ }^{\circ} \mathrm{C}, 2 \mathrm{~h}$; then $\mathrm{Bu}_{4} \mathrm{NF}, \mathrm{THF}, 25^{\circ} \mathrm{C}, 10 \mathrm{~h} ; 70 \%$; (xiv) $\mathrm{Bu}_{2} \mathrm{Cu}(\mathrm{CN}) \mathrm{Li}{ }_{2}, \mathrm{THF},-78$ to $0{ }^{\circ} \mathrm{C}, 2 \mathrm{~h} ; 60 \% ;(x v) \mathrm{NaN}, \mathrm{MeOH}, \mathrm{reflux}, 2 \mathrm{~h} ; 70 \%$.

substitutions of iodohydrins (R)-16 with $\mathrm{KCN}$ and (S)20 with $\mathrm{NaN}_{3}$ were al so carried out smoothly to give the cyano diol (R)-36 and the azido diol (R)-37. The possibility of Payne rearrangements ${ }^{23}$ in the above-mentioned reactions was not overlooked. Nevertheless, the degenerative Payne rearrangements should not change the stereochemical outcomes, as that demonstrated in the transformation of (S)-21 to (S)-27.
The iodohydrin (R)-16 reacted with $\mathrm{Me}_{2} \mathrm{SO}_{4}$ and $\mathrm{NaN}_{3}$ subsequently to give the $\beta$-azido al cohol (S)-38, which was treated with triphenyl phosphine to give the aziridine 39 (56\% ee favoring the R-enantiomer) with partial racemization. The anal ogous transformation of $\beta$-azido al cohols is known to yield the corresponding aziridines with inverse chirality. ${ }^{26}$ Due to the nature of the tertiary propargyl alcohol 38, its transformation to the aziridine 
Scheme 4. Reductive Removal of lodine Atom and Application to the Synthesis of Vitamin $D_{3}$ Metabolite and Prostaglandin Analoga

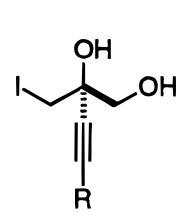

16-18, 21 (S-isomers)<smiles>CC1(C)OC[C@@](C#CI)(CI)O1</smiles>

(S)-51<smiles>C=C(C#Cc1ccccc1)CO</smiles>

52

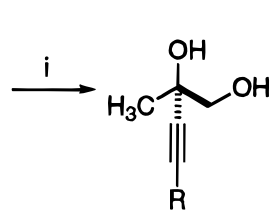

(S) $-28 \mathrm{R}=\mathrm{Ph}$ (S)-45 $\mathrm{R}=\mathrm{PhCH}_{2} \mathrm{OCH}_{2}$ (S) $-46 \mathrm{R}=\mathrm{Me}_{3} \mathrm{Si}$ (S) $-47 \mathrm{R}=\mathrm{Me}_{3} \mathrm{C}$<smiles>CC(C)O[AsH3]</smiles><smiles>C[C@](O)(CO)CCCO</smiles>

(S) -53 use for the side chain $\left(C_{22}-C_{26}\right)$ of vitamin $D_{3}$ metabolite 3

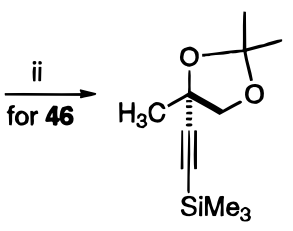

(S) -48

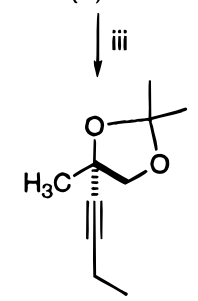

(S) -49

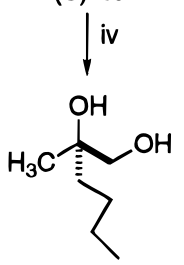

(S) -50 use for the $\omega$-chain $\left(\mathrm{C}_{15}-\mathrm{C}_{20}\right)$ of prostaglandin analog 1

a Reagents and conditions: (i) $\mathrm{Bu}_{3} \mathrm{SnH}, \mathrm{AlBN}, \mathrm{PhH}$, reflux; or $\mathrm{LiAlH}_{4}, \mathrm{Et}_{2} \mathrm{O}, 25^{\circ} \mathrm{C}, 2 \mathrm{~h}$; 28, 74\%; 45, 56\%; 46, 83\%; 47, 80\%; (ii) $\mathrm{Me}_{2} \mathrm{CO}, \mathrm{CuSO}_{4}, \mathrm{p}-\mathrm{TsOH}, 25^{\circ} \mathrm{C}, 4 \mathrm{~h} ; 80 \%$; (iii) MeLi, THF, 0-25 ${ }^{\circ} \mathrm{C}, 2 \mathrm{~h}$, then Etl, HMPA, $25^{\circ} \mathrm{C}, 15 \mathrm{~h}$; $40 \%$; (iv) $\mathrm{H}_{2}, \mathrm{Pd} / \mathrm{C}, \mathrm{p}-\mathrm{TsOH}$, $\mathrm{MeOH}, 25^{\circ} \mathrm{C}$, $10 \mathrm{~h}$; $43 \%$; (v) $\mathrm{Bu}_{2} \mathrm{Cu}(\mathrm{CN}) \mathrm{Li}{ }_{2}, \mathrm{THF},-78{ }^{\circ} \mathrm{C}, 2 \mathrm{~h}$; or $\mathrm{CH}_{3}\left(\mathrm{CH}_{2}\right)_{11} \mathrm{MgBr}, \mathrm{Li}_{2} \mathrm{CuCl}_{4}, \mathrm{THF},-78$ to $+25^{\circ} \mathrm{C}, 12 \mathrm{~h} ; 80 \%$; (vi) $\mathrm{H}_{2}, \mathrm{Pd} / \mathrm{C}, \mathrm{EtOH}, 25^{\circ} \mathrm{C}, 15 \mathrm{~h} ; 40 \%$.

39 might involve both the $\mathrm{S}_{\mathrm{N}} 2$ and $\mathrm{S}_{\mathrm{N}} 1$ processes to different degrees and eventually led to partial racemization. The iodohydrin (S)-16 was treated with $\mathrm{NaH}$, followed by $\mathrm{t}-\mathrm{BuMe}_{2} \mathrm{SiCl}$, to give the glycidol silyl ether (R)-42. The reaction of (R)-42 with a Grignard reagent (route 3) afforded a diol (S)-43 after removal of the silyl group. The reaction of the iodohydrin (S)-20 with a cuprate reagent $\mathrm{Bu}_{2} \mathrm{Cu}(\mathrm{CN}) \mathrm{Li}_{2}$ proceeded in a different fashion to give the allenediol 44. The product was obtained presumably via an $\mathrm{S}_{\mathrm{N}} 2^{\prime}$ mechanism, in which the cuprate reagent attacked the triple bond of the glycidol intermediate.

By a procedure similar to that described for the transformation of the iodohydrin (S)-16 to the diol (S)28, the iodohydrins (S)-17, (S)-18, and (S)-21 were reduced (Scheme 4) with $\mathrm{Bu}_{3} \mathrm{SnH}$ to give the alkynyl diols (S)-45, (S)-46, and (S)-47, respectively. Catalytic hydrogenation of (S)-45 caused a simultaneous saturation of the triple bond and cleavage of the benzyl group to give (S)-2-methyl-1,2,5-pentanetriol, ${ }^{3}$ which is a precursor for construction of the side chain of a vitamin $D_{3}$ metabolite 3. The acetonide (S)-51, derived from (S)-16, reacted with $\mathrm{Bu}_{2} \mathrm{Cu}(\mathrm{CN}) \mathrm{Li}_{2}$ or with a mixed reagent of $\mathrm{n}-\mathrm{C}_{12} \mathrm{H}_{25^{-}}$ $\mathrm{MgBr} / \mathrm{Li}_{2} \mathrm{CuCl}_{4}$ to afford an allyl al cohol 52 in $80 \%$ yield. The organometallic reagents appeared to attack the iodine atom instead of undergoing a nucleophilic substitution.

(26) Shao, H.; Zhu, Q.; Goodman, M. J . Org. Chem. 1995, 60, 790. (27) Fujimoto, Y.; Yadav, J. S.; Sih, C. J . Tetrahedron Lett. 1980, $21,2481$.

Scheme 5. Synthesis of (1S,5R)-(-)-F rontalina

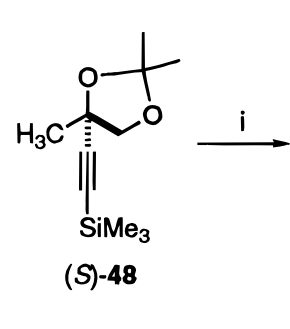

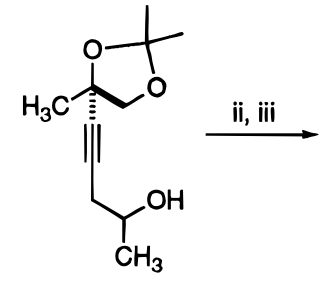

(S)-54

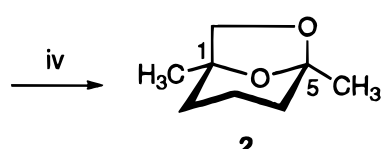

$(1 S, 5 R)-(-)-$ frontalin<smiles>CC(=O)CCC[C@]1(C)COC(C)(C)O1</smiles>

(S)-55

\begin{abstract}
a Reagents and conditions: (i) MeLi, THF, $25^{\circ} \mathrm{C}, 2 \mathrm{~h}$; $\mathrm{BF}_{3} \cdot \mathrm{OEt}_{2}$, $-78{ }^{\circ} \mathrm{C}$, $10 \mathrm{~min}$; 2-methyloxirane, $-78{ }^{\circ} \mathrm{C}$, $30 \mathrm{~min}$; $81 \%$; (ii) PDC, molecular sieves, $\mathrm{CH}_{2} \mathrm{Cl}_{2}, 25^{\circ} \mathrm{C}, 4 \mathrm{~h}$; (iii) $\mathrm{H}_{2}, \mathrm{Pd} / \mathrm{C}, \mathrm{EtOAC}, 25^{\circ} \mathrm{C}$, $4 \mathrm{~h}$; $61 \%$ for two steps; (iv) $\mathrm{HCl}(10 \mathrm{~N}), \mathrm{Et}_{2} \mathrm{O}, 25^{\circ} \mathrm{C}, 15 \mathrm{~h} ; 60 \%$.
\end{abstract}

The alkynyl alcohol (S)-18 is a versatile building block. Compound ( $\mathrm{S}$ )-18 was reduced by $\mathrm{Bu}_{3} \mathrm{SnH}$, giving the diol (S)-46, and protected as the acetonide (S)-48. The silyl group in (S)-48 was removed by MeLi to generate an alkynyllithium intermediate, which was subsequently alkylated with iodoethane to give (S)-49. By the assistance of p-toluenesulfonic acid, hydrogenation of $\mathbf{4 9}$ in $\mathrm{MeOH}$ also effected a hydrolysis of the acetonide moiety to give a single product, (S)-2-methyl-1,2-hexanediol 27 (50), which has been utilized to synthesize the $\omega$-chain of a potent prostaglandin analog (1). Attempts to trap the alkynyllithium intermediate with propylene oxide failed. Fortunately, alkylation with propylene oxide was carried out successfully by a prior treatment of the alkynyllithium intermediate with $\mathrm{BF}_{3} \cdot \mathrm{OEt}_{2}$ (Scheme 5), giving the desired homopropargyl alcohol (S)-54 in $81 \%$ yield. Oxidation of (S)-54 with pyridinium dichromate, followed by hydrogenation, afforded the ketone (S)55. Hydrolysis of (S)-55 under acidic conditions gave a dihydroxy ketone, which underwent intramolecular acetalization to yield an aggregation pheromone (1S,5R)(-)-frontalin. ${ }^{2}$

\section{Conclusion}

Although a general enzymatic resolution of tertiary alcohols by extension of their reactive sites, as that in the hydroperoxy acetate $\mathbf{7}$ and $\beta$-alkoxy alcohol 8, was not achieved, we demonstrate a more successful approach by adding $\mathrm{CH}_{2} \mathrm{OH}$ tethers to tertiary alcohols, as that shown in the substrates of 11-22, for efficient resolution with the catalysis of lipases. Thus, the lipase-catalyzed reactions occur at the primary hydroxyl groups while the enantioselectivity is controlled by the tertiary $\mathrm{C}-\mathrm{O}$ centers. By selection of appropriate substituents, such as iodine atom, phenyl, and alkynyl groups, extremely high enantioselectivity is realized. The obtained enantiomerically pure compounds are versatile building blocks for the synthesis of drugs and natural products. Wealso propose a model to show the importance of size, distance, and electron effect of substituents in lipase-catalyzed reactions. The great enhancement of enantiosel ectivity by a triple bond in the substrate is most remarkable.

\section{Experimental Section}

Melting points are uncorrected. Optical rotations were measured on a digital polarimeter with a cuvette of $1 \mathrm{~cm}$ 
length. ${ }^{1} \mathrm{H}$ NMR spectra were recorded at 200, 300, or 400 $\mathrm{MHz} ;{ }^{13} \mathrm{C}$ NMR spectra were recorded at 50,75 , or $100 \mathrm{MHz}$. Tetramethylsilane ( $\delta=0 \mathrm{ppm})$ was used as internal standard in ${ }^{1} \mathrm{H}$ NMR spectra. Mass spectra were recorded at an ionizing voltage of 70 or $20 \mathrm{eV}$. Merck silica gel 60F sheets were used for analytical thin-layer chromatography. Column chromatography was performed on $\mathrm{SiO}_{2}$ (70-230 mesh); gradients of EtOAc and n-hexane were used as eluents. GC was performed on a gas chromatograph equipped with a flame ionization detector. High-pressure liquid chromatography was carried out on a liquid chromatograph equipped with UV $(254 \mathrm{~nm})$ and refractive index detectors. Enantiomeric excesses of the remaining substrate, $\mathrm{ee}_{\mathrm{s}}$, and the product, $\mathrm{ee}_{\mathrm{p}}$, were determined by HPLC analysis using a Chiralcel OB or OD column ( $25 \mathrm{~cm} \times 0.46 \mathrm{~cm}$ i.d.) with the indicated flow rate of elution. The $E$ value was calculated according to $E=\ln \left[1-c\left(1+e_{p}\right)\right] /$ $\ln \left[1-c\left(1-e_{p}\right)\right]$, where $c$ is conversion $\left[c=e_{s} /\left(e_{s}+e e_{p}\right)\right] .{ }^{12 f}$ The reaction was monitored either by GC analysis on an OV-1 column ( $2 \%$ on Chromosorb WHP/80-100 mesh, $2 \mathrm{~m} \times 0.32$ $\mathrm{cm}$ i.d.) with $30 \mathrm{~mL} / \mathrm{min}$ flow rate of $\mathrm{N}_{2}$ or by HPLC analysis on a Nucleosil 100-7 $(7 \mu \mathrm{m})$ column $(15 \mathrm{~cm} \times 0.46 \mathrm{~cm}$ i.d. $)$ with the indicated eluent.

Lipase AK (Pseudomonas sp.), lipase AP-6 (Aspergillus niger), lipase AY (C. cylindracea), and lipase MAP (Mucor meihe) were purchased from Amano Pharm. Co., Ltd., J apan. Lipase OF (C. cylindracea) and lipase MY (C. cylindracea) were from Meito-Sangyo Co., Ltd., J apan. Porcine pancreas lipase (PPL, type II) was from Sigma, USA. These crude enzymes were often used for enzymatic reactions without further purification, and lipase AK was occasionally immobilized on Hyflo Supercel (Fluka, 2-25 $\mu \mathrm{m}$ ) for the reactions. The reagents and solvents (isopropenyl acetate, vinyl acetate, t-BuOMe, THF , and toluene) were dried according to standard procedure and stored over molecular sieves (4 $\AA$ ) before use.

General Procedure for Lipase-Catalyzed Acetylation and Stereochemical Assignment (Tables 1 and 2). Procedure A. The al cohol $( \pm)-\mathbf{1 3}(384 \mathrm{mg}, 1.4 \mathrm{mmol})$ was stirred (800-1000 rpm) with isopropenyl acetate (11 mL) and lipase AK (390 mg) at $25^{\circ} \mathrm{C}$ for $30 \mathrm{~h}$. The mixture was filtered through a pad of Celite, and the filtrate was concentrated and chromatographed on a silica gel column by elution with EtOAc/ hexane (3:7) to give $193 \mathrm{mg}$ (43\%) of the acetate 13a (94\% ee favoring the R-isomer) and to recover $222 \mathrm{mg} \mathrm{(57 \% )} \mathrm{of} \mathrm{the}$ alcohol $\mathbf{1 3}$ (70\% ee favoring the S-isomer). The recovered alcohol 13 was treated with $\mathrm{K}_{2} \mathrm{CO}_{3}$ in $\mathrm{MeOH}$ at $30{ }^{\circ} \mathrm{C}$ for $8 \mathrm{~h}$ to give glycidol 14, of which the ee value was determined by HPLC analysis. The recovered alcohol $\mathbf{1 3}$ was treated with $\mathrm{Bu}_{3} \mathrm{SnH}$ (1 equiv) and AIBN (catalytic amount) in refluxing benzene for $4 \mathrm{~h}$ to give (S)-(+)-10. ${ }^{21}$ This experiment indicated that the predominant enantiomer of $\mathbf{1 3}$ had the (S)-configuration. The ee value of the product $\mathbf{1 3} \mathbf{a}$ and the absolute configuration of its major enantiomer were determined by the procedure similar to that for $\mathbf{1 3}$

Procedure B. The alcohol $( \pm)-\mathbf{1 6}(710 \mathrm{mg}, 2.35 \mathrm{mmol})$ was treated with vinyl acetate $(0.65 \mathrm{~mL}, 3 \mathrm{mmol})$ by catalysis of PPL $(710 \mathrm{mg})$ in t-BuOMe (12 mL) at $19{ }^{\circ} \mathrm{C}$ for $9 \mathrm{~h}$ to give 405 $\mathrm{mg}(50 \%)$ of the acetate $\mathbf{1 6 a}$ (>97\% ee favoring the R-isomer) and to recover $355 \mathrm{mg}(50 \%)$ of the alcohol 16 (>97\% ee favoring the S-isomer). The ee values were determined by HPLC analysis. The absolute configuration of the major enantiomers were determined by correlation with 2-methylglycerol 1,2-acetonide 30 (Scheme 2) as follows.

(S)-(-)-16 (350 mg, $1.12 \mathrm{mmol}$ ) was treated with $\mathrm{Bu}_{3} \mathrm{SnH}$ $(0.46 \mathrm{~mL}, 1.68 \mathrm{mmol})$ and AIBN $(36 \mathrm{mg})$ in refluxing benzene (25 mL) for $2 \mathrm{~h}$ to give (S)-2-methyl-4-phenyl-3-butyne-1,2diol (28) (151 mg, 74\%). The sample was treated with acetone $(20 \mathrm{~mL}), \mathrm{CuSO}_{4}(3 \mathrm{~g})$, and p-TSA (catalytic amount) at $25^{\circ} \mathrm{C}$ for $4 \mathrm{~h}$ to give the acetonide (S)-29. The crude acetonide was dissolved in $\mathrm{MeOH}(8 \mathrm{~mL})$ and treated with ozone at $0{ }^{\circ} \mathrm{C}$. The reaction was monitored by TLC analysis. After completion of the ozonolysis during a period of $1.5 \mathrm{~h}$, the mixture was purged with $\mathrm{N}_{2}$ to remove the remaining ozone. The mixture was heated for $15 \mathrm{~min}$, concentrated, dissolved in anhydrous THF $(10 \mathrm{~mL})$, and treated with $\mathrm{LiAlH}_{4}(95 \mathrm{mg}, 2.5 \mathrm{mmol})$ at $25^{\circ} \mathrm{C}$ for $12 \mathrm{~h}$. The reaction was quenched by addition of water at $0{ }^{\circ} \mathrm{C}$. The mixture was extracted with EtOAC and chromatographed on a silica gel column (EtOAc/hexane (1:1)) to give (S)-2-methylglycidol acetonide (30) $(20.6 \mathrm{mg}, 17 \%$ from 28): $[\alpha]^{25} \mathrm{D}-7.61$ (c $1.05, \mathrm{CH}_{2} \mathrm{Cl}_{2}$ ) (lit. ${ }^{24}[\alpha]^{25} \mathrm{D}-5.33$ (c 0.3 , $\left.\mathrm{CH}_{2} \mathrm{Cl}_{2}\right)$ ).

2-(I odomethyl)-4-phenyl-3-butyne-1,2-diol (16): solid; mp 94-95 ${ }^{\circ} \mathrm{C}$; $[\alpha]^{25} \mathrm{D}-8.0$ (c 2.5, EtOH; S-isomer); HPLC (Chiralcel OD, 2-propanol/hexane (10:90), $1 \mathrm{~mL} / \mathrm{min}) \mathrm{t}_{R} 12.3$ min (R-isomer), 15.0 min (S-isomer); IR (K Br) 3341, $2314 \mathrm{~cm}^{-1}$; ${ }^{1} \mathrm{H}$ NMR $\left(300 \mathrm{MHz} \mathrm{CDCl}_{3}\right) \delta 7.43-7.45(2 \mathrm{H}, \mathrm{m}), 7.28-7.31$ $(3 \mathrm{H}, \mathrm{m}), 3.92(1 \mathrm{H}, \mathrm{d}, \mathrm{J}=11.1 \mathrm{~Hz}), 3.83(1 \mathrm{H}, \mathrm{d}, \mathrm{J}=11.1 \mathrm{~Hz})$, $3.59(1 \mathrm{H}, \mathrm{d}, \mathrm{J}=10.2 \mathrm{~Hz}), 3.54(1 \mathrm{H}, \mathrm{d}, \mathrm{J}=10.2 \mathrm{~Hz}), 2.93(1 \mathrm{H}$, $\mathrm{s}, \mathrm{OH})), 2.21(1 \mathrm{H}, \mathrm{br} \mathrm{s}, \mathrm{OH}) ;{ }^{13} \mathrm{C} \mathrm{NMR}(75 \mathrm{MHz}$, acetone-d 6$) \delta$ 132.6, 129.6, 129.4, 123.6, 90.5, 85.7, 71.3, 68.5, 14.7; MS m/ z (rel intensity) $302\left(3, \mathrm{M}^{+}\right), 144(100)$; HRMS calcd for $\mathrm{C}_{11} \mathrm{H}_{12} \mathrm{O}_{2} \mathrm{l}$ $\left(\mathrm{M}^{+}\right)$301.9803, found 301.9809.

1-Acetoxy-2-(iodomethyl)-4-phenyl-3-butyn-2-ol (16a): oil; $[\alpha]^{25} \mathrm{D}-10.2$ (c $2.5, \mathrm{EtOH}$; >97\% ee favoring the R-isomer); HPLC (Chiralcel OD, 2-propanol/hexane (10:90), 0.5 $\mathrm{mL} / \mathrm{min}$ ) $\mathrm{t}_{\mathrm{R}} 15.4 \mathrm{~min}$ (R-isomer), $17.2 \mathrm{~min}$ (S-isomer); IR (neat) $3417,2230,1737 \mathrm{~cm}^{-1}$; ${ }^{1} \mathrm{H}$ NMR $\left(200 \mathrm{MHz} \mathrm{CDCl}_{3}\right) \delta 7.39-$ $7.44(2 \mathrm{H}, \mathrm{m}), 7.27-7.32(3 \mathrm{H}, \mathrm{m}), 4.43(1 \mathrm{H}, \mathrm{d}, \mathrm{J}=11.3 \mathrm{~Hz})$, $4.36(1 \mathrm{H}, \mathrm{d}, \mathrm{J}=11.3 \mathrm{~Hz}), 3.53(2 \mathrm{H}, \mathrm{s}), 3.19(1 \mathrm{H}, \mathrm{s}, \mathrm{OH}), 2.11$ $(3 \mathrm{H}, \mathrm{s}) ;{ }^{13} \mathrm{C}$ NMR $\left(50 \mathrm{MHz} \mathrm{CDCl}_{3}\right) \delta 185.2,131.8,128.9,128.2$ $121.4,86.6,86.3,68.9,67.9,20.8,13.4 ; \mathrm{MS} \mathrm{m} / \mathrm{z}$ (rel intensity) $344\left(5, \mathrm{M}^{+}\right), 271(100)$; HRMS calcd for $\mathrm{C}_{13} \mathrm{H}_{13} \mathrm{Ol}\left(\mathrm{M}^{+}\right)$ 344.9909, found 344.9919.

1-(Hydroxymethyl)-1-(phenylethynyl)oxirane (23). The iodohydrin (S)-16 (205 mg, $0.67 \mathrm{mmol} ;>97 \%$ ee) in THF (10 $\mathrm{mL}$ ) was treated with $\mathrm{NaH}(750 \mathrm{mg}, 30 \mathrm{mmol})$ at $0{ }^{\circ} \mathrm{C}$ for 30 min to give the oxirane (S)-23 (116 mg, 99\%): oil; $[\alpha]^{25}{ }_{\mathrm{D}}-11.7$ (c 4.8, EtOH; S-isomer, >97\% ee); ${ }^{13} \mathrm{C} \mathrm{NMR} \mathrm{(75} \mathrm{MHz}^{\mathrm{C}} \mathrm{CDCl}_{3}$ ) $\delta 131.9,128.9,128.2,121.4,84.8,84.7,62.9,51.5,51.4$; HRMS calcd for $\mathrm{C}_{11} \mathrm{H}_{10} \mathrm{O}_{2}\left(\mathrm{M}^{+}\right)$174.0680, found 174.0679 .

3-Azido-2-phenyl-1,2-propanediol (31). A mixture of oxirane (S)-14 (74 mg, $0.49 \mathrm{mmol}$; >97\% ee), $\mathrm{NaN}_{3}$ (162 mg, $2.45 \mathrm{mmol}$ ), and $\mathrm{NH}_{4} \mathrm{Cl}(57 \mathrm{mg})$ in $\mathrm{H}_{2} \mathrm{O} / \mathrm{MeOH}(1: 8)$ solution $(5 \mathrm{~mL})$ was refluxed for $5.5 \mathrm{~h}$. The mixture was concentrated and taken up with EtOAc. The organic phase was washed with aqueous $\mathrm{NaHCO}_{3}$ solution, dried $\left(\mathrm{Na}_{2} \mathrm{SO}_{4}\right)$, and filtered. The filtrate was concentrated and chromatographed on a silica gel column by elution with EtOAc/hexane $(30: 70)$ to give the azido compound (R)-31 (54 mg, 57\%): oil; $[\alpha]^{25} \mathrm{D}-55.81$ (c 2.65, EtOH; R-isomer, >97\% ee); IR (neat) 3413, $2104\left(\mathrm{~N}_{3}\right) \mathrm{cm}^{-1}$; ${ }^{1} \mathrm{H}$ NMR $\left(200 \mathrm{MHz}^{\mathrm{CDCl}}\right)_{3} \delta 7.44-7.26(5 \mathrm{H}, \mathrm{m}), 3.80(1 \mathrm{H}, \mathrm{d}$, $\mathrm{J}=11.5 \mathrm{~Hz}), 3.72(1 \mathrm{H}, \mathrm{d}, \mathrm{J}=11.5 \mathrm{~Hz}), 3.64(1 \mathrm{H}, \mathrm{d}, \mathrm{J}=13.0$ $\mathrm{Hz}), 3.57(1 \mathrm{H}, \mathrm{d}, \mathrm{J}=13.0 \mathrm{~Hz}), 3.34(1 \mathrm{H}, \mathrm{br} \mathrm{s}), 2.52(1 \mathrm{H}, \mathrm{br} \mathrm{s})$; ${ }^{13} \mathrm{C}$ NMR $\left(75 \mathrm{MHz} \mathrm{CDCl}_{3}\right) \delta 140.8,128.5,127.9,125.2,76.3$, 67.5, 57.7; MS m/ z (rel intensity) $194\left(1, \mathrm{M}^{+}\right), 137$ (100); HRMS calcd for $\mathrm{C}_{8} \mathrm{H}_{8} \mathrm{ON}{ }_{3}\left(\mathrm{M}^{+}-\mathrm{CH}_{2} \mathrm{OH}\right) 162.0667$, found 162.0675 .

3-(Phenylthio)-2-phenylpropane-1,2-diol (32). The oxirane (S)-14 (79 mg, $0.52 \mathrm{mmol}$; >97\% ee) was treated with $\mathrm{PhSH}(0.08 \mathrm{~mL}, 0.78 \mathrm{mmol})$ and $\mathrm{Et}_{3} \mathrm{~N}(2 \mathrm{~mL}, 1.75 \mathrm{mmol})$ at $25^{\circ} \mathrm{C}$ for $15 \mathrm{~h}$ to give (S)-32 (98 mg, 71\%): solid; mp 105-106 ${ }^{\circ} \mathrm{C} ;[\alpha]^{25} \mathrm{D}+15.2$ (c 4.2, EtOH; S-isomer, >97\% ee); IR ( $\mathrm{KBr}$ ) $3171 \mathrm{~cm}^{-1}$; ${ }^{1} \mathrm{H}$ NMR $\left(300 \mathrm{MHz} \mathrm{CDCl}_{3}\right) \delta 7.42-7.13(10 \mathrm{H}, \mathrm{m})$, $3.77(1 \mathrm{H}, \mathrm{d}, \mathrm{J}=11.3 \mathrm{~Hz}), 3.72(1 \mathrm{H}, \mathrm{d}, \mathrm{J}=11.3 \mathrm{~Hz}), 3.58(1 \mathrm{H}$, $\mathrm{d}, \mathrm{J}=13.3 \mathrm{~Hz}), 3.52(1 \mathrm{H}, \mathrm{d}, \mathrm{J}=13.3 \mathrm{~Hz}), 3.37(1 \mathrm{H}, \mathrm{br} \mathrm{s}), 2.31$ $(1 \mathrm{H}, \mathrm{br} \mathrm{s}) ;{ }^{13} \mathrm{C} N M R\left(75 \mathrm{MHz} \mathrm{CDCl}_{3}\right) \delta 142.1,136.0,129.9$, $128.9,128.9,128.3,127.6,126.4,125.4,76.4,69.3,44.1$; MS $\mathrm{m} / \mathrm{z}$ (rel intensity) $260\left(2, \mathrm{M}^{+}\right), 124(100)$; HRMS calcd for $\mathrm{C}_{15} \mathrm{H}_{16} \mathrm{O}_{2} \mathrm{~S}\left(\mathrm{M}^{+}\right) 260.0871$, found 260.0873 .

3,4-Dihydroxy-3-phenylbutanenitrile (33). The oxirane (S)-14 (75 mg, $0.50 \mathrm{mmol}$; >97\% ee) was treated with $\mathrm{KCN}$ $(6.5 \mathrm{mg}, 0.09 \mathrm{mmol})$ and acetone cyanohydrin $(2 \mathrm{~mL}, 21.9$ $\mathrm{mmol}$ ) at $25{ }^{\circ} \mathrm{C}$ for $24 \mathrm{~h}$ to give (S)-33 (38 mg, 42\%): solid; 117-118 ${ }^{\circ} \mathrm{C} ;[\alpha]^{25} \mathrm{D}-9.26$ (c 1.2, EtOH; S-isomer, >97\% ee); IR (KBr) 3437, 2217 (CN) cm ${ }^{-1}$; ${ }^{1} \mathrm{H}$ NMR $(200 \mathrm{MHz}$, acetone$\left.\mathrm{d}_{6}\right) \delta 7.60-7.55(2 \mathrm{H}, \mathrm{m}), 7.40-7.27(3 \mathrm{H}, \mathrm{m}), 3.78(1 \mathrm{H}, \mathrm{d}, \mathrm{J}=$ $11.0 \mathrm{~Hz}), 3.68(1 \mathrm{H}, \mathrm{d}, \mathrm{J}=11.0 \mathrm{~Hz}), 3.11(1 \mathrm{H}, \mathrm{d}, \mathrm{J}=16.8 \mathrm{~Hz})$, $3.01(1 \mathrm{H}, \mathrm{d}, \mathrm{J}=16.8 \mathrm{~Hz}) ;{ }^{13} \mathrm{C}$ NMR $\left(75 \mathrm{MHz}\right.$, acetone- $\left.\mathrm{d}_{6}\right) \delta$ 143.4, 128.8, 128.1, 126.2, 118.3, 75.3, 69.5, 32.5; MS m/ z (rel intensity) $177\left(2, \mathrm{M}^{+}\right), 105(100)$; HRMS calcd for $\mathrm{C}_{10} \mathrm{H}_{11} \mathrm{O}_{2} \mathrm{~N}$ $\left(\mathrm{M}^{+}\right), 177.0789$, found 177.0795 .

1-(Methoxymethyl)-1-(phenylethynyl)aziridine (39). The iodo compound ( $\mathrm{R}$ )-16 (280 mg, $0.92 \mathrm{mmol}$; > 97\% ee) was treated with $\mathrm{NaH}(750 \mathrm{mg}, 30 \mathrm{mmol})$ and $\mathrm{Me}_{2} \mathrm{SO}_{4}(0.13 \mathrm{~mL}$, $1.4 \mathrm{mmol})$ in THF $(5 \mathrm{~mL})$ at $23^{\circ} \mathrm{C}$ for $1 \mathrm{~h}$ to give a crude product of the methyl ether. The crude product was treated 
with $\mathrm{NaN}_{3}$ (59 mg, $9.2 \mathrm{mmol}$ ) in refluxing $\mathrm{MeOH} / \mathrm{H}_{2} \mathrm{O}$ (10:1) solution (11 mL) for $2 \mathrm{~h}$ to give (S)-38 (160 mg, $75 \%)$ : oil; $[\alpha]^{24} \mathrm{D}$ +58.22 (c 7.5, EtOH; S-isomer, $>97 \%$ ee).

The azido compound (S)-38 (95 mg, $0.44 \mathrm{mmol}$ ) was treated with $\mathrm{PPh}_{3}(126 \mathrm{mg}, 0.48 \mathrm{mmol})$ in $\mathrm{MeCN}(10 \mathrm{~mL})$ at $23^{\circ} \mathrm{C}$ for $5 \mathrm{~h}$ to give 39 (54 mg, 71\%; 56\% ee favoring the R-isomer): oil; $[\alpha]^{25} \mathrm{D}-12.5$ (c $0.68, \mathrm{EtOH} ; 56 \%$ ee favoring the R-isomer); HPLC (Chiralcel OD, 2-propanol/hexane (10:90), $1 \mathrm{~mL} / \mathrm{min}$ ) $t_{R} 13.6 \mathrm{~min}$ (S-isomer), $15.0 \mathrm{~min}$ (R-isomer); IR (neat) 3282, $2240 \mathrm{~cm}^{-1} ;{ }^{1} \mathrm{H}$ NMR $\left(200 \mathrm{MHz} \mathrm{CDCl}_{3}\right) \delta 7.42-7.37(2 \mathrm{H}, \mathrm{m})$, 7.27-7.22 (3H, m), $3.55(2 \mathrm{H}, \mathrm{s}), 3.42(3 \mathrm{H}, \mathrm{s}), 2.20(1 \mathrm{H}, \mathrm{br} \mathrm{s})$, $1.96(1 \mathrm{H}, \mathrm{br} \mathrm{s}) ;{ }^{13} \mathrm{C}$ NMR $\left(50 \mathrm{MHz}, \mathrm{CDCl}_{3}\right) \delta 131.7,128.1,128.0$, 122.3, 89.1, 80.3, 75.9, 59.0, 32.0, 29.3; MS m/ z (rel intensity) $187\left(5, \mathrm{M}^{+}\right), 155(100)$; HRMS calcd for $\mathrm{C}_{12} \mathrm{H}_{13} \mathrm{O}_{1} \mathrm{~N}\left(\mathrm{M}^{+}\right)$ 187.0997, found 187.0992.

1-Methoxy-2,3-diphenyl-2-propanol (41). The oxirane (S)-14 (450 mg, 3 mmol; >97\% ee) was treated with $\mathrm{NaH}$ (750 $\mathrm{mg}, 30 \mathrm{mmol})$ and $\mathrm{Me}_{2} \mathrm{SO}_{4}(\mathrm{~mL}, 3.3 \mathrm{mmol})$ in THF $(15 \mathrm{~mL})$ at $23^{\circ} \mathrm{C}$ for $1 \mathrm{~h}$ to give (S)-1-(methoxymethyl)-1-phenyloxirane 40 (501 mg, 99\%). The ether (S)-40 (487 mg, $2.97 \mathrm{mmol}$ ) was treated with $\mathrm{PhLi}$ ( $2.96 \mathrm{~mL}$ of $3 \mathrm{M}$ solution in cyclohexane/ $\left.\mathrm{Et}_{2} \mathrm{O}\right)$ and $\mathrm{CuCN}(400 \mathrm{mg}, 4.45 \mathrm{mmol})$ in THF $(3 \mathrm{~mL})$ at -78 ${ }^{\circ} \mathrm{C}$ and then at $0{ }^{\circ} \mathrm{C}$ for $1.5 \mathrm{~h}$ to give (S)-41 (632 mg, 88\%): oil; $[\alpha]^{30}-26.3$ (c 0.05, EtOH; S-isomer, >97\% ee); IR (neat) 3450 $\mathrm{cm}^{-1}$; ${ }^{1} \mathrm{H}$ NMR $\left(200 \mathrm{MHz} \mathrm{CDCl}_{3}\right) \delta 7.34-6.78(10 \mathrm{H}, \mathrm{m}) 3.66$ $(1 \mathrm{H}, \mathrm{d}, \mathrm{J}=9.2 \mathrm{~Hz}), 3.60(1 \mathrm{H}, \mathrm{d}, \mathrm{J}=9.2 \mathrm{~Hz}), 3.38\left(3 \mathrm{H}, \mathrm{s}, \mathrm{OCH}_{3}\right)$, $3.13\left(2 \mathrm{H}, \mathrm{s}, \mathrm{CH}_{2} \mathrm{Ph}\right), 2.83(\mathrm{H}, \mathrm{S}, \mathrm{OH}) ; \mathrm{MS} \mathrm{m} / \mathrm{z}$ (rel intensity) $242\left(1, \mathrm{M}^{+}\right), 91(100)$; HRMS calcd for $\mathrm{C}_{16} \mathrm{H}_{18} \mathrm{O}_{2}\left(\mathrm{M}^{+}\right)$242.1306, found 242.1300 .

3-(Hydroxymethyl)-1-phenyl-1-heptadecyn-3-ol (43). The iodo compound (S)-16 (151 mg, $0.50 \mathrm{mmol}$; >97\% ee) was treated with $\mathrm{NaH}$ (125 mg, $5 \mathrm{mmol}$ ) and t-BuMes $\mathrm{SiCl}(0.75$ $\mathrm{mL}$ of $1 \mathrm{M}$ THF solution) in THF $(5 \mathrm{~mL})$ at $25^{\circ} \mathrm{C}$ for $3 \mathrm{~h}$ to give a silyl ether (S)-42 (127 mg, 88\%). The silyl ether was treated with dodecylmagnesium bromide $(6 \mathrm{~mL}$ of $1 \mathrm{M} \mathrm{THF}$ solution) in THF at $0{ }^{\circ} \mathrm{C}$ for $2 \mathrm{~h}$ to give a crude product. The product was subsequently treated with $\mathrm{Bu}_{4} \mathrm{NF}(172 \mathrm{mg}, 0.66$ $\mathrm{mmol}$ ) in THF (10 mL) to give (S)-43 (110 mg, 70\%): oil; $[\alpha]^{23} \mathrm{D}$ -32.1 (c 2.0, EtOH; S-isomer, >97\% ee); IR (neat) 3338, 2240 $\mathrm{cm}^{-1}$; ${ }^{1} \mathrm{H}$ NMR $\left(300 \mathrm{MHz} \mathrm{CDCl}_{3}\right) \delta 7.42-7.39(2 \mathrm{H}, \mathrm{m}), 7.30-$ $7.27(3 \mathrm{H}, \mathrm{m}), 3.74(1 \mathrm{H}, \mathrm{d}, \mathrm{J}=11.0 \mathrm{~Hz}), 3.57(1 \mathrm{H}, \mathrm{d}, \mathrm{J}=11.0$ $\mathrm{Hz}), 2.25(2 \mathrm{H}, \mathrm{br} \mathrm{s}), 1.73-1.54(4 \mathrm{H}, \mathrm{m}), 1.22(22 \mathrm{H}, \mathrm{br} \mathrm{s}), 0.85$ $(3 \mathrm{H}, \mathrm{t}, \mathrm{J}=6.8 \mathrm{~Hz}) ;{ }^{13} \mathrm{C} \mathrm{NMR}\left(75 \mathrm{MHz} \mathrm{CDCl}_{3}\right) \delta 131.7,128.5$, 128.2, 122.5, 89.5, 85.4, 72.3, 69.7, 37.9, 31.9, 29.7, 29.6, 29.5, 29.3, 24.1, 22.6, 14.1; MS m/ z (rel intensity) 341 (3), 327 (100, $\left.\mathrm{M}^{+}-\mathrm{CH}_{2} \mathrm{OH}\right)$; HRMS calcd for $\mathrm{C}_{23} \mathrm{H}_{35} \mathrm{O}_{2}\left(\mathrm{M}^{+}-\mathrm{CH}_{2} \mathrm{OH}\right)$ 327.2687, found 327.2692.

4-Butyl-2-(hydroxymethyl)-2,3-decadien-1-ol (44). The iodo compound (S)-20 (99 mg, $0.32 \mathrm{mmol})$ in THF (1.5 mL) was treated with $\mathrm{Bu}_{2} \mathrm{Cu}(\mathrm{CN}) \mathrm{Li}_{2}(3 \mathrm{~mL}$ of $0.43 \mathrm{M}$ solution in THF) at $-78{ }^{\circ} \mathrm{C}$ for $1 \mathrm{~h}$ and then at $0{ }^{\circ} \mathrm{C}$ for an additional $1 \mathrm{~h}$ to give 44 (46 mg, 60\%): oil; IR (neat) 3352, 1955 (allene) $\mathrm{cm}^{-1}$; ${ }^{1} \mathrm{H}$ NMR $\left(200 \mathrm{MHz} \mathrm{CDCl}_{3}\right) \delta 4.16(4 \mathrm{H}, \mathrm{s}), 1.99-1.92(6 \mathrm{H}, \mathrm{m}, 2$ $\left.\mathrm{CH}_{2}, 2 \mathrm{OH}\right), 1.39-1.24(12 \mathrm{H}, \mathrm{m}) 0.89-0.81(6 \mathrm{H}, \mathrm{m}) ;{ }^{13} \mathrm{C} N M R$ $\left(50 \mathrm{MHz} \mathrm{CDCl}_{3}\right) \delta 196.5,109.9,105.6,62.7,32.8,32.5,31.7$, 30.0, 28.9, 27.8, 22.6, 22.3, 13.9, 13.8; MS m/ z (rel intensity) $240\left(3, \mathrm{M}^{+}\right), 109(100)$; HRMS calcd for $\mathrm{C}_{15} \mathrm{H}_{28} \mathrm{O}_{2}\left(\mathrm{M}^{+}\right)$ 240.2089 , found 240.2089 .

2-Methyl-1,2-hexanediol (50). The diol (S)-46 (487 mg, $2.83 \mathrm{mmol}$; >97\% ee) was treated with acetone $(20 \mathrm{~mL})$ by the catalysis of $\mathrm{CuSO}_{4}(6 \mathrm{~g})$ and p-TsOH (2 grains) at $25^{\circ} \mathrm{C}$ for 4 $\mathrm{h}$ to give the corresponding acetonide (S)-48 (483 mg, 80\%): oil; $[\alpha]^{25} \mathrm{D}-5.21$ (c 2.5, $\mathrm{CHCl}_{3}$; S-isomer, $>97 \%$ ee). The acetonide (S)-48 (200 mg, $0.9 \mathrm{mmol}$; >97\% ee) was treated with MeLi $\left(0.89 \mathrm{~mL}\right.$ of $1.5 \mathrm{M}$ of hexane solution) at $25^{\circ} \mathrm{C}$ for $2 \mathrm{~h}$. Etl $(0.4 \mathrm{~mL}, 0.9 \mathrm{mmol})$ and HMPA $(1 \mathrm{~mL})$ were added. The mixture was stirred at $25^{\circ} \mathrm{C}$ for $18 \mathrm{~h}$ to give a crude product 49 (57 mg). The product was subjected to hydrogenation by the catalysis of $\mathrm{Pd} / \mathrm{C}(5 \%, 100 \mathrm{mg}$ ) and $\mathrm{p}$-TsOH (catalytic amount) in $\mathrm{MeOH}\left(10 \mathrm{~mL}\right.$ ) at $25^{\circ} \mathrm{C}$ for $10 \mathrm{~h}$ to give (S)-50 (19 mg, 43\%): oil; $[\alpha]^{25} \mathrm{D}-4.8$ (c $0.95, \mathrm{CHCl}_{3}$; S-isomer, $>97 \%$ ee) (lit. ${ }^{27}[\alpha]^{25}-3.0\left(\mathrm{c} 0.7, \mathrm{CHCl}_{3}\right)$ ).

(28) Sugai, T.; Kakeya, H.; Ohta, H. J . Org. Chem. 1990, 55, 4643.
2-Methylene-4-phenyl-3-butyn-1-ol (52). The iodo compound (S)-16 (152 mg, $0.5 \mathrm{mmol}$; >97\% ee) was treated with acetone $(20 \mathrm{~mL})$ by the catalysis of $\mathrm{CuSO}_{4}(2 \mathrm{~g})$ and p-TsOH (2 grains) at $25^{\circ} \mathrm{C}$ for $4 \mathrm{~h}$ to give the corresponding acetonide (S)-51 (136 mg, 78\%). The acetonide in THF (4 mL) was treated $\mathrm{Bu}_{2} \mathrm{Cu}(\mathrm{CN}) \mathrm{Li}_{2}(6 \mathrm{~mL}$ of $0.33 \mathrm{M}$ solution in THF) at $-78{ }^{\circ} \mathrm{C}$ for $2 \mathrm{~h}$ to give 52 (49 mg, 80\%): oil; IR (neat) 3358, $2205 \mathrm{~cm}^{-1} ;{ }^{1} \mathrm{H}$ NMR $\left(200 \mathrm{MHz} \mathrm{CDCl}_{3}\right) \delta 7.36-7.29(2 \mathrm{H}, \mathrm{m})$, 7.22-7.16 (3H, m), 5.49-5.46 $(2 \mathrm{H}, \mathrm{m}), 4.11(2 \mathrm{H}, \mathrm{s}), 2.18(1 \mathrm{H}$, br S, OH); ${ }^{13} \mathrm{C} N M R\left(50 \mathrm{MHz} \mathrm{CDCl}_{3}\right) \delta 131.5,131.1,128.3$, 128.2, 122.6, 120.2, 90.6, 87.0, 65.0; MS m/ z (rel intensity) $158\left(100, \mathrm{M}^{+}\right)$; HRMS calcd for $\mathrm{C}_{11} \mathrm{H}_{10} \mathrm{O}\left(\mathrm{M}^{+}\right)$158.0731, found 158.0722.

2-Methyl-1,2,5-pentanetriol (53). The diol (S)-45 (220 $\mathrm{mg}, 1 \mathrm{mmol}$; >97\% ee) was subjected to hydrogenation by the catalysis of $\mathrm{Pd} / \mathrm{C}(5 \%, 100 \mathrm{mg})$ in $\mathrm{EtOH}$ at $25^{\circ} \mathrm{C}$ for $15 \mathrm{~h}$ to

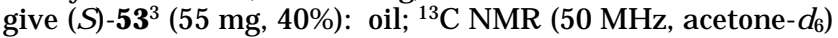
$\delta 72.5,70.3,63.2,35.9,27.8,24.1$.

5-(2,2,4-Trimethyl-1,3-dioxolan-4-yl)-4-pentyn-2-ol (54). The acetonide (S)-48 (212 mg, $1 \mathrm{mmol} ;>97 \%$ ee) was treated with MeLi ( $1 \mathrm{~mL}, 1.6 \mathrm{M}$ of hexane solution) in THF $(5 \mathrm{~mL})$ at $25^{\circ} \mathrm{C}$ for $2 \mathrm{~h}$. The mixture was cooled to $-78{ }^{\circ} \mathrm{C}$, and $\mathrm{BF}_{3} \mathrm{OEt}_{2}$ $(0.13 \mathrm{~mL}, 1 \mathrm{mmol})$ was added. After $10 \mathrm{~min}$, 1-methyloxirane (116 mg, $2 \mathrm{mmol}$ ) was added. The mixture was stirred for 30 min, and the reaction was quenched by addition of $\mathrm{Et}_{3} \mathrm{~N}$ and saturated $\mathrm{NaHCO}_{3}$. The mixture was extracted with EtOAc. The combined extracts were dried $\left(\mathrm{Na}_{2} \mathrm{SO}_{4}\right)$ and filtered. The filtrate was concentrated and chromatographed on a $\mathrm{SiO}_{2}$ column by elution with EtOAc/hexane (20:80) to give (S)-54 (160 mg, 81\%): oil; [ $\alpha]^{25} \mathrm{D}-9.44$ (c 9.0, $\mathrm{CHCl}_{3}$; S-isomer, $>97 \%$ ee); IR (neat) 3424, $2236 \mathrm{~cm}^{-1}$; ${ }^{1} \mathrm{H}$ NMR (200 MHz, $\left.\mathrm{CDCl}_{3}\right) \delta$ $4.05(1 \mathrm{H}, \mathrm{d}, \mathrm{J}=8.1 \mathrm{~Hz}), 3.91-3.82(1 \mathrm{H}, \mathrm{m}), 3.70(1 \mathrm{H}, \mathrm{d}, \mathrm{J}=$ $8.1 \mathrm{~Hz}), 2.35(1 \mathrm{H}, \mathrm{br} \mathrm{s}, \mathrm{OH}), 2.31(2 \mathrm{H}, \mathrm{d}, \mathrm{J}=5.9 \mathrm{~Hz}), 1.48$ $(3 \mathrm{H}, \mathrm{s}), 1.46(3 \mathrm{H}, \mathrm{s}), 1.33(3 \mathrm{H}, \mathrm{s}), 1.18(3 \mathrm{H}, \mathrm{d}, \mathrm{J}=6.2 \mathrm{~Hz}) ;{ }^{13} \mathrm{C}$ NMR $\left(50 \mathrm{MHz}_{2} \mathrm{CDCl}_{3}\right) \delta 110.4,84.5,80.4,75.7,73.7,66.1$, 29.1, 26.9, 26.9, 26.1, 22.2; MS m/ z (rel intensity) 183 (51, $\left.\mathrm{M}^{+}-\mathrm{CH}_{3}\right), 72(100)$; HRMS calcd for $\mathrm{C}_{10} \mathrm{H}_{15} \mathrm{O}_{3}\left(\mathrm{M}^{+}-\mathrm{CH}_{3}\right)$ 183.1021, found 183.1019.

5-(2,2,4-Trimethyl-1,3-dioxolan-4-yl)pentan-2-one (55). The alcohol (S)-54 (289 mg, $1.45 \mathrm{mmol}$; > 97\% ee) was treated with pyridinium dichromate $(1.36 \mathrm{~g}, 3.62 \mathrm{mmol})$ in the presence of molecular sieves $(4 \AA)$ in $\mathrm{CH}_{2} \mathrm{Cl}_{2}$ at $25^{\circ} \mathrm{C}$ for $4 \mathrm{~h}$. The mixture was filtered and rinsed with $\mathrm{Et}_{2} \mathrm{O}$. The filtrate was concentrated to give a crude product, which was subjected to hydrogenation (1 atm) by the catalysis of $\mathrm{Pd} / \mathrm{C}(5 \%, 150 \mathrm{mg})$ in EtOAc ( $15 \mathrm{~mL}$ ) at $25^{\circ} \mathrm{C}$ for $4 \mathrm{~h}$ to give (S)-55 (176 mg, 61\%; $>97 \%$ ee): oil; IR (neat) $2981,1707 \mathrm{~cm}^{-1} ;{ }^{1} \mathrm{H}$ NMR $(200 \mathrm{MHz}$, $\left.\mathrm{CDCl}_{3}\right) \delta 3.75(1 \mathrm{H}, \mathrm{d}, \mathrm{J}=8.3 \mathrm{~Hz}), 3.66(1 \mathrm{H}, \mathrm{d}, \mathrm{J}=8.3 \mathrm{~Hz})$, $2.42(2 \mathrm{H}, \mathrm{t}, \mathrm{J}=6.9 \mathrm{~Hz}), 2.10(3 \mathrm{H}, \mathrm{s}), 1.67-1.39(4 \mathrm{H}, \mathrm{m}), 1.35$ $(3 \mathrm{H}, \mathrm{s}), 1.34(3 \mathrm{H}, \mathrm{s}), 1.24(3 \mathrm{H}, \mathrm{s}) ; \mathrm{MS} \mathrm{m} / \mathrm{z}$ (rel intensity) 200 $\left(1, \mathrm{M}^{+}\right), 185(45), 72(100)$; HRMS calcd for $\mathrm{C}_{11} \mathrm{H}_{20} \mathrm{O}_{3}\left(\mathrm{M}^{+}\right)$ 200.1412 , found 200.1432 .

(1S,5R)-(-)-F rontalin (2). Compound (S)-55 (176 mg, 0.88 $\mathrm{mmol}$; $>97 \%$ ee) was treated with $\mathrm{HCl}(10 \mathrm{~N}, 0.5 \mathrm{~mL})$ in $\mathrm{Et}_{2} \mathrm{O}$ $(2 \mathrm{~mL})$ at $25{ }^{\circ} \mathrm{C}$ for $15 \mathrm{~h}$. After addition of $\mathrm{NaHCO}_{3}, \mathrm{Na}_{2} \mathrm{SO}_{4}$ and $\mathrm{Et}_{2} \mathrm{O}$, the mixture was filtered. The solvent was evaporated, the residue was distilled (Kugelrohr, 95-100 ${ }^{\circ} \mathrm{C}, 100$ $\mathrm{mmHg}$ ) to give (1S,5R)-frontalin (76 mg, 60\%; >97\% ee). [ $\alpha]^{23} \mathrm{D}$ -52.5 (c 2.0, $\mathrm{Et}_{2} \mathrm{O}$ ) [lit. ${ }^{28}[\alpha]^{22} \mathrm{D}-52.8$ (c 1.64, $\mathrm{Et}_{2} \mathrm{O}$ ). ${ }^{1} \mathrm{H} N M R$ $\left(200 \mathrm{MHz} \mathrm{CDCl}_{3}\right) \delta 3.92(1 \mathrm{H}, \mathrm{d}, \mathrm{J}=6.3 \mathrm{~Hz}), 3.45(1 \mathrm{H}, \mathrm{d}, \mathrm{J}$ $=6.3 \mathrm{~Hz}), 1.26-2.02(6 \mathrm{H}, \mathrm{m}), 1.44(3 \mathrm{H}, \mathrm{s}), 1.34(3 \mathrm{H}, \mathrm{s})$.

Acknowledgment. We thank the National Science Council for financial support (Grant No. NSC84-2113M002-010).

Supporting Information Available: Additional experimental procedures, spectral data, and authentic NMR spectra of new compounds (64 pages). This material is contained in libraries on microfiche, immediately follows this article in the microfilm version of the journal, and can be ordered from the ACS; see any current masthead page for ordering information.

J O970236U 